Article

\title{
Hydrogen-Etched $\mathrm{TiO}_{2-x}$ as Efficient Support of Gold Catalysts for Water-Gas Shift Reaction
}

\author{
Li Song (1), Zhufeng Lu, Yuting Zhang, Qi Su and Lei Li * \\ College of Biological, Chemical Sciences and Engineering, Jiaxing University, 118 Jiahang Road, Jiaxing 314001, \\ China; songli@mail.zjxu.edu.cn (L.S.); luzhufeng@mail.zjxu.edu.cn (Z.L.); 15757390515@163.com (Y.Z.); \\ suqi2311412281@163.com (Q.S.) \\ * Correspondence: leili@mail.zjxu.edu.cn; Tel.: +86-0573-8364-3852
}

Received: 30 December 2017; Accepted: 9 January 2018; Published: 15 January 2018

\begin{abstract}
Hydrogen-etching technology was used to prepare $\mathrm{TiO}_{2-x}$ nanoribbons with abundant stable surface oxygen vacancies. Compared with traditional $\mathrm{Au}-\mathrm{TiO}_{2}$, gold supported on hydrogen-etched $\mathrm{TiO}_{2-x}$ nanoribbons had been proven to be efficient and stable water-gas shift (WGS) catalysts. The disorder layer and abundant stable surface oxygen vacancies of hydrogen-etched $\mathrm{TiO}_{2-x}$ nanoribbons lead to higher microstrain and more metallic $\mathrm{Au}^{0}$ species, respectively, which all facilitate the improvement of WGS catalytic activities. Furthermore, we successfully correlated the WGS thermocatalytic activities with their optoelectronic properties, and then tried to understand WGS pathways from the view of electron flow process. Hereinto, the narrowed forbidden band gap leads to the decreased Ohmic barrier, which enhances the transmission efficiency of "hot-electron flow". Meanwhile, the abundant surface oxygen vacancies are considered as electron traps, thus promoting the flow of "hot-electron" and reduction reaction of $\mathrm{H}_{2} \mathrm{O}$. As a result, the WGS catalytic activity was enhanced. The concept involved hydrogen-etching technology leading to abundant surface oxygen vacancies can be attempted on other supported catalysts for WGS reaction or other thermocatalytic reactions.
\end{abstract}

Keywords: water-gas shift reaction; black $\mathrm{TiO}_{2-x}$; gold catalysts; oxygen vacancies

\section{Introduction}

Hydrogen is a promising clean, efficient and sustainable energy source and can be a suitable candidate to reduce the dependence on fossil fuels. In this sense, the water-gas shift (WGS) reaction $\left(\mathrm{CO}+\mathrm{H}_{2} \mathrm{O}=\mathrm{CO}_{2}+\mathrm{H}_{2}\right)$ is crucial in industrially producing pure hydrogen, because the reaction provides not only hydrogen generation but also $\mathrm{CO}$ cleanup. However, the traditional WGS catalysts (e.g., $\mathrm{Cu}-\mathrm{Zn}-\mathrm{Al}, \mathrm{Fe}-\mathrm{Cr}$ and $\mathrm{Co}-\mathrm{Mo}$ based catalysts) usually need long and tedious pretreatment procedures or are easily pyrophoric [1]. To develop new and more efficient WGS catalysts, supported catalysts have been believed to be good candidate. For example, both precious metals (e.g., $\mathrm{Pt}, \mathrm{Au}$, $\mathrm{Pd}, \mathrm{Rh}, \mathrm{Ir}$ or $\mathrm{Ru}$ ) [2,3] and cheap transition metals (e.g., $\mathrm{Cu}$ or $\mathrm{Ni}$ ) [4,5] were deposited on various supports including $\mathrm{TiO}_{2}$ [6-17], $\mathrm{CeO}_{2}$ [18-23], $\mathrm{Mo}_{2} \mathrm{C}$ [24-26], $\mathrm{FeO}_{x}$ [27-29], $\mathrm{Co}_{3} \mathrm{O}_{4}$ [30], $\mathrm{Al}_{2} \mathrm{O}_{3}$ [31,32], $\mathrm{ZrO}_{2}[33,34], \mathrm{CeO}_{2}-\mathrm{TiO}_{2}$ [35], $\mathrm{CeO}_{2}-\mathrm{ZrO}_{2}$ [36,37] and $\mathrm{CeO}_{2}-\mathrm{La}_{2} \mathrm{O}_{3}$ [38]. Au- $\mathrm{TiO}_{2}$ catalysts have been given considerable attentions for WGS activities, due to the high activity and low side reactions of dispersed $\mathrm{Au}\left[38\right.$ ], and some advantages of $\mathrm{TiO}_{2}$ supports (e.g., low price, easy preparation, adjustable properties and strong interaction with active metal).

$\mathrm{Au}-\mathrm{TiO}_{2}$ has been considered as a bifunctional supported catalyst [39-41], suggesting that the WGS activity can be strongly affected by not only the properties of active gold species but also the structural and surface properties of appropriate supports. For example, the nature of the support has an important effect on the activation and stabilization of the gold nanoparticles [39]. Similarly, the 
surface structures of ceria supports ((100) surface versus (111) surface) have a strong effect on the morphology, size, and atomic interface structures of gold [42]. Furthermore, the support can directly participate by activating $\mathrm{H}_{2} \mathrm{O}$ molecules [12], which dissociate into $\mathrm{H}_{2}$ and $\mathrm{O}$ atom on the surface oxygen vacancies of $\mathrm{CeO}_{2}$ support during the WGS reaction [43]. Notably, in terms of $\mathrm{Pt} / \mathrm{TiO}_{2}$ (110) and $\mathrm{Au} / \mathrm{TiO}_{2}$ model catalysts, the oxygen vacancies of $\mathrm{TiO}_{2}$ supports have played a critical role in the dissociation of $\mathrm{H}_{2} \mathrm{O}$, which determines the WGS catalytic activity [41,44,45]. Also, the $\mathrm{H}_{2} \mathrm{O}$ dissociation on the surface oxygen vacancy is generally considered as the rate determining step [44,45]. From the above, in order to design an effective $\mathrm{Au}-\mathrm{TiO}_{2}$ WGS catalyst, it is essential to develop appropriate supports, which prefer to $\mathrm{TiO}_{2}$ supports with abundant surface oxygen vacancies. Generally, most scientists devoted to increase the oxygen vacancies by adding metal or nonmetal impurities $[7,15,46]$. However, the amount of introduced dopants is generally not enough to form desired oxygen vacancies, and the introduction of dopants will lead to a complicated catalyst system and will confuse us with respect to the real reaction mechanism.

Recently, a dopant-free black $\mathrm{TiO}_{2}$ (i.e., pure $\mathrm{TiO}_{2}$ phase) was obtained through high-pressure hydrogenation [47]. The black $\mathrm{TiO}_{2}$ presents the surface disorder layer with $\mathrm{Ti}^{3+}$ ions, surface oxygen vacancies and point defects, which are exactly required to show high WGS activities. For instance, Panagiotopoulou et al. [48] reported that partial reduction of $\mathrm{TiO}_{2}$ support results in the creation of new active sites for $\mathrm{CO}$ adsorption, probably located at metallic $\mathrm{Pt}$ in contact with $\mathrm{Ti}^{3+}$ ions. However, to date, black $\mathrm{TiO}_{2}$ is mainly considered for photocatalysis [49-53], as well as supercapacitors [54], lithium and $\mathrm{Al}$-ion batteries [55]. To our best knowledge, the black $\mathrm{TiO}_{2}$ based catalyst has not been reported for the WGS reaction, or even for other thermocatalytic reactions.

In addition, metal-support interactions are known to influence the catalytic activity. Recently, it has been reported that "hot-electron flow" can be formed between metal-oxide interfaces during exothermic chemical processes, and the "hot-electron flow" has strongly influenced the catalytic activity of CO oxidation [46,56-58]. It is well-known that the WGS reaction is a typical exothermic redox reaction with electron exchange. Therefore, it is interesting, based on electron flow processes, to investigate the effect of black $\mathrm{TiO}_{2}$ surface properties (e.g., oxygen vacancies) on their WGS catalytic activity.

Here, a blue black $\mathrm{TiO}_{2-x}$ nanoribbon rich in stable surface oxygen vacancies was prepared by hydrogen-etching technology. Blue black $\mathrm{TiO}_{2-x}$ nanoribbon had been proven to be efficient and stable support of gold catalyst for WGS reaction. According to the in-depth characterization results, we try to understand WGS pathway from the view of the electron flow process. Hereinto, the reduction of the forbidden band gap leads to the decrease in Ohmic barrier; thus, the transmission efficiency of "hot-electron flow" is improved. Meanwhile, the abundant surface oxygen vacancies become electron traps, thus promoting the flow of "hot-electron" and reduction reaction of $\mathrm{H}_{2} \mathrm{O}$, so as to enhance the WGS catalytic activity.

\section{Results}

\subsection{Catalytic Activities and Stabilities}

As shown in Figure 1a, $\mathrm{Au}-\mathrm{TiO}_{2-x}-\mathrm{N}$ catalyst shows higher $\mathrm{CO}$ conversion than the corresponding $\mathrm{Au}-\mathrm{TiO}_{2}-\mathrm{N}$ catalyst from 200 to $400{ }^{\circ} \mathrm{C}$, indicating that the $\mathrm{TiO}_{2-x}-\mathrm{N}$ support can obviously improve WGS catalytic activities compared with the white $\mathrm{TiO}_{2}-\mathrm{N}$ support. For example, compared with $\mathrm{Au}-\mathrm{TiO}_{2}-\mathrm{N}$ catalyst, the $\mathrm{CO}$ conversion of $\mathrm{Au}-\mathrm{TiO}_{2-x}-\mathrm{N}$ catalyst increase by $59 \%$ (i.e., from $46.7 \%$ to $74 \%$ at $300{ }^{\circ} \mathrm{C}$ ). Therefore, $\mathrm{H}_{2}$ atmosphere leads to higher catalytic activity, because the only difference between the two $\mathrm{Au}-\mathrm{TiO}_{2}$ catalysts is calcination atmosphere $\left(\mathrm{H}_{2}\right.$ or air) of supports.

To make a more realistic comparison of catalytic activities, turnover frequencies (TOFs) were measured in the kinetic region with negligible heat and mass-transfer effects (keeping CO conversion below $12 \%$ ), as shown in Figure $1 \mathrm{~b}$. Au- $\mathrm{TiO}_{2-x}-\mathrm{N}$ catalyst presents higher TOF and slight smaller active energy $\left(E_{a}\right)$ than $\mathrm{Au}-\mathrm{TiO}_{2}-\mathrm{N}$ catalyst. For example, the TOF of $\mathrm{Au}-\mathrm{TiO}_{2-x}-\mathrm{N}$ catalyst arrives $0.73 \mathrm{~s}^{-1}$ at 
$200{ }^{\circ} \mathrm{C}$ (Table S1), nearly double that of $\mathrm{Au}-\mathrm{TiO}_{2}-\mathrm{N}$ catalyst $\left(0.37 \mathrm{~s}^{-1}\right.$ at $\left.20{ }^{\circ} \mathrm{C}\right)$. A slight decrease in $E_{a}$ from $60.4 \pm 1.9 \mathrm{~kJ} / \mathrm{mol}\left(\mathrm{Au}-\mathrm{TiO}_{2}-\mathrm{N}\right)$ to $56.4 \pm 1.8 \mathrm{~kJ} / \mathrm{mol}\left(\mathrm{Au}-\mathrm{TiO}_{2-x}-\mathrm{N}\right)$ is also observed. As shown in Table S2, compared with other Au or Pt supported on $\mathrm{TiO}_{2}$ catalysts reported in literatures, our $\mathrm{Au}-\mathrm{TiO}_{2-x}-\mathrm{N}$ catalyst presented higher TOF. Even comparing with the other candidate catalysts, the activity of our $\mathrm{Au}-\mathrm{TiO}_{2-x}-\mathrm{N}$ catalyst is still ranked at the top.
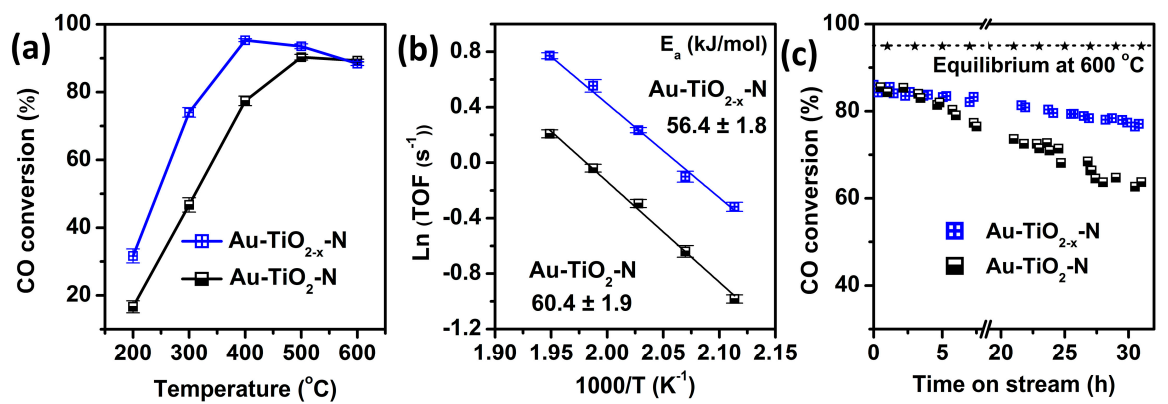

Figure 1. (a) The $\mathrm{CO}$ conversions of $\mathrm{Au}-\mathrm{TiO}_{2}$ and $\mathrm{Au}-\mathrm{TiO}_{2-x}$ catalysts as a function of temperature; (b) Arrhenius plots of TOF over $\mathrm{Au}-\mathrm{TiO}_{2}$ and $\mathrm{Au}-\mathrm{TiO}_{2-x}$ catalysts in the reaction temperature range of $200-240{ }^{\circ} \mathrm{C}$; (c) The CO conversions at $600{ }^{\circ} \mathrm{C}$ as a function of time on stream. Dried feed gas: $12.5 \%$ $\mathrm{CO}$ and $87.5 \% \mathrm{~N}_{2}$.

Figure $1 \mathrm{c}$ shows high-temperature stabilities of the $\mathrm{Au}-\mathrm{TiO}_{2}$ catalysts for WGS at $600{ }^{\circ} \mathrm{C}$. The $\mathrm{CO}$ conversion of $\mathrm{Au}-\mathrm{TiO}_{2-x}-\mathrm{N}$ catalyst only decrease by $19.1 \%$ (from $86 \%$ to $69.6 \%$ ) over a $32-\mathrm{h}$ run, which obviously presents higher stability than $\mathrm{Au}-\mathrm{TiO}_{2}-\mathrm{N}$ catalyst (decrease by $36.8 \%$ from $85.5 \%$ to $54.7 \%$ ). Meanwhile, our $\mathrm{Au}-\mathrm{TiO}_{2-x}-\mathrm{N}$ catalyst has a comparable or even higher stability than the $\mathrm{Au}-\mathrm{TiO}_{2}$ and $\mathrm{Au} / \mathrm{CeZrO}_{4}$ catalysts reported in the literature [14,37].

Therefore, the colors of $\mathrm{TiO}_{2}$ supports seemingly have an important effect on the WGS catalytic activity and stability; thus, $\mathrm{H}_{2}$ atmosphere has an indelible function.

\subsection{Structural Properties}

As shown in Figure 2a,b, $\mathrm{TiO}_{2}$ precursors were calcined in air and high-purity $\mathrm{H}_{2}$ atmospheres, which produce white $\mathrm{TiO}_{2}-\mathrm{N}$ and blue black $\mathrm{TiO}_{2-x}-\mathrm{N}$ supports, respectively. As shown in Figure $2 \mathrm{~b}, \mathrm{c}$, both $\mathrm{TiO}_{2-x}-\mathrm{N}$ and $\mathrm{TiO}_{2}-\mathrm{N}$ presents the nanoribbon morphology. Thus, $\mathrm{H}_{2}$ atmosphere has little effect on their morphology. However, $\mathrm{H}_{2}$ atmosphere indeed has significant effect on their colors and catalytic activities, which must be attributed to other reasons. For this reason, the structural and optoelectronic properties of various $\mathrm{TiO}_{2}$ supports and $\mathrm{Au}$ catalysts should be further and deeply investigated with the aid of various characterization techniques.
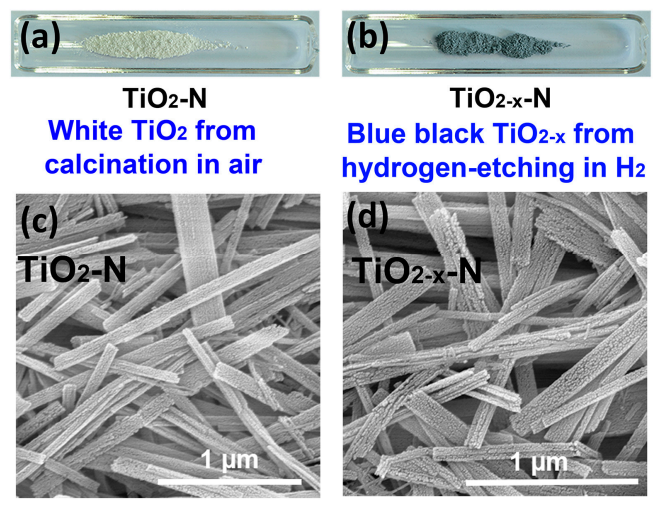

Figure 2. (a,b) The photographs of white $\mathrm{TiO}_{2}$ support calcined in air and blue black $\mathrm{TiO}_{2-x}$ support calcined in $\mathrm{H}_{2} ;(\mathbf{c}, \mathbf{d})$ Scanning electron microscopy (SEM) images of $\mathrm{TiO}_{2-x}-\mathrm{N}$ and $\mathrm{TiO}_{2}-\mathrm{N}$. 
As shown in Figure 3a,d, $\mathrm{TiO}_{2-x}-\mathrm{N}$ and $\mathrm{TiO}_{2}-\mathrm{N}$ supports were decorated with Au particles (dark dots). The surface-averaged Au cluster diameters $\left(d_{\mathrm{TEM}}\right)$ of $\mathrm{Au}-\mathrm{TiO}_{2-x}-\mathrm{N}$ and $\mathrm{Au}-\mathrm{TiO}_{2}-\mathrm{N}$ are $9.1 \mathrm{~nm}$ and $7.5 \mathrm{~nm}$, respectively (Figure 3g,h). Impressively, the high resolution transmission electron microscopy (HRTEM) images were further investigated in detail. As shown in Figure $3 b$, the surface of $\mathrm{TiO}_{2-x}-\mathrm{N}$ nanocrystals became disordered where the disordered outer layer surrounds a crystalline core. After Au was deposited on $\mathrm{TiO}_{2}$ supports, $\mathrm{Au}-\mathrm{TiO}_{2-x}-\mathrm{N}$ retains the microstructure composed of crystalline core and disordered shell, in spite of the fact that the thickness of the disordered surface layer has been reduced. However, the HRTEM images of $\mathrm{TiO}_{2}-\mathrm{N}$ and $\mathrm{Au}-\mathrm{TiO}_{2}-\mathrm{N}$ show no obvious disordered shell near the surface region (Figure 3e,f). Thus, the results indicate that $\mathrm{H}_{2}$ atmosphere resulted in the surface structure rearrangement and disordered shell, in agreement with the reported results [47,49], so the calcination in $\mathrm{H}_{2}$ atmosphere was chosen as the hydrogen-etching technology.
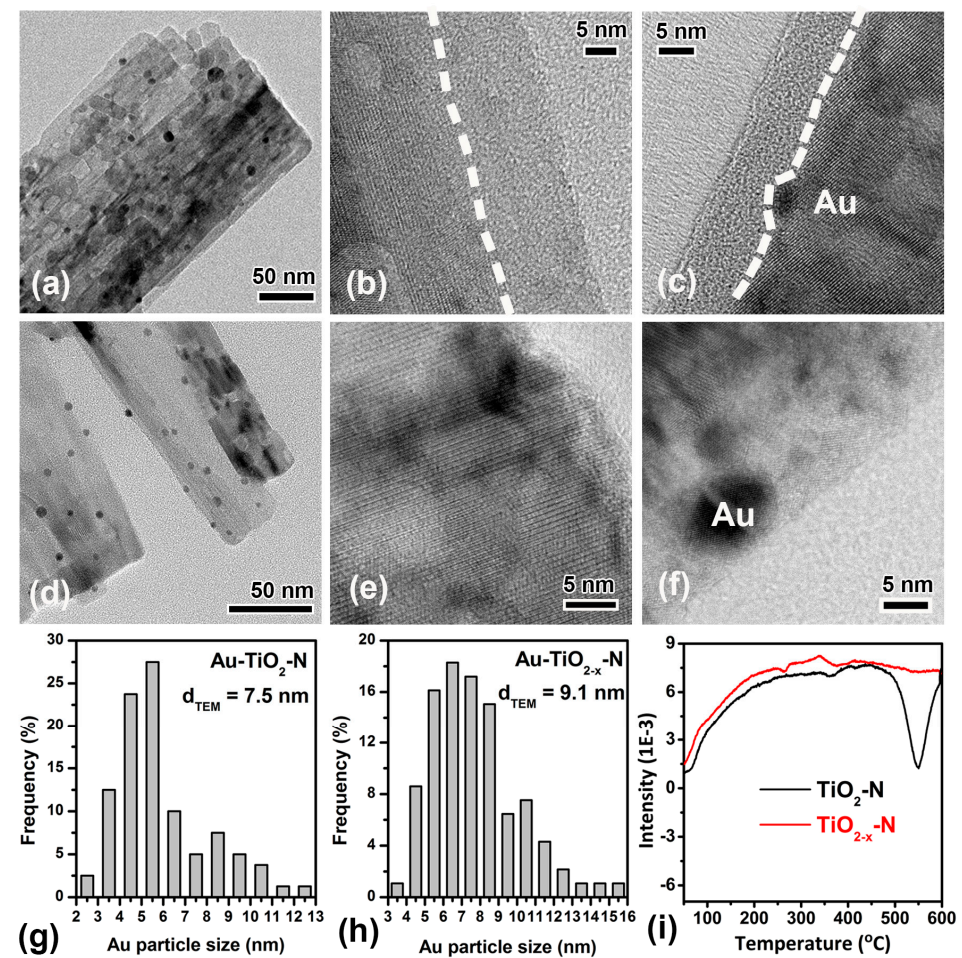

Figure 3. TEM images of $\mathrm{Au}-\mathrm{TiO}_{2}-\mathrm{N}(\mathbf{a})$ and $\mathrm{Au}-\mathrm{TiO}_{2-x}-\mathrm{N}(\mathbf{d})$. HRTEM images of $\mathrm{TiO}_{2-x}-\mathrm{N}(\mathbf{b})$, $\mathrm{Au}-\mathrm{TiO}_{2-x}-\mathrm{N}(\mathbf{c}), \mathrm{TiO}_{2}-\mathrm{N}(\mathbf{e})$ and $\mathrm{Au}-\mathrm{TiO}_{2}-\mathrm{N}(\mathbf{f})$. The dash line indicates the interface between the disordered layer and crystalline core. Surface-averaged Au cluster diameters $\left(d_{\mathrm{TEM}}\right)$ and cluster diameter distributions of $\mathrm{Au}-\mathrm{TiO}_{2}-\mathrm{N}(\mathrm{g})$ and $\mathrm{Au}-\mathrm{TiO}_{2-x}-\mathrm{N}(\mathbf{h}) . \mathrm{H}_{2}-\mathrm{TPR}$ profiles of $\mathrm{TiO}_{2-x}-\mathrm{N}$ and $\mathrm{TiO}_{2}-\mathrm{N}$ supports (i).

Furthermore, the evolution of surface structure was also confirmed by the $\mathrm{H}_{2}$-TPR results (Figure 3i). As shown in Figure $3 i$, their reduction peaks occur at $550{ }^{\circ} \mathrm{C}$, in very good agreement with the temperature of hydrogen-etching. The reducible capacity of $\mathrm{TiO}_{2-x}-\mathrm{N}$ is smaller than that of $\mathrm{TiO}_{2}-\mathrm{N}$, indicating that the surface oxygen species of $\mathrm{TiO}_{2-x}-\mathrm{N}$ are smaller than those of $\mathrm{TiO}_{2}-\mathrm{N}$. In other words, disordered shell should stem from the decrease of oxygen species $\left(\mathrm{TiO}_{2}+x \mathrm{H}_{2}=\mathrm{TiO}_{2-x}\right.$ $\left.+x \mathrm{H}_{2} \mathrm{O}\right)$ [48] due to $\mathrm{H}_{2}$ reduction during the hydrogen-etching technology.

As shown in Figure 4, $\mathrm{TiO}_{2}-\mathrm{N}$ and $\mathrm{TiO}_{2}-x-\mathrm{N}$ present two sets of diffraction peaks: anatase $\mathrm{TiO}_{2}$ marked with "\$" (JCPDS file No. 71-1166), and monoclinic $\mathrm{TiO}_{2}$ marked with "\#" (JCPDS file No. 74-1940). After $\mathrm{Au}$ was deposited on the above-mentioned $\mathrm{TiO}_{2}$ supports, the all diffraction peaks remain unchanged and the diffraction peaks of any Au species cannot be observed. Furthermore, compared with $\mathrm{TiO}_{2}-\mathrm{N}$ and $\mathrm{Au}-\mathrm{TiO}_{2}-\mathrm{N}$, diffraction peaks of $\mathrm{TiO}_{2-x}-\mathrm{N}$ and $\mathrm{Au}-\mathrm{TiO}_{2-x}-\mathrm{N}$ became 
broader, embodying that the FWHM of the diffraction peak at $25.3^{\circ}$ increased from $0.564^{\circ}$ to $0.597^{\circ}$ and from $0.602^{\circ}$ to $0.609^{\circ}$, respectively (Table 1). Usually, the broadening of diffraction peaks may be due to the increase of microstrain $(\Delta d / d)$ in anatase [18,59] (i.e., increase from 0.600 to 0.617 and from 0.615 to 0.625, Table 1) and monoclinic $\mathrm{TiO}_{2}$ (the increase from 0.702 to 0.720 and from 0.802 to 0.812 , Table S3). The above increase of microstrain might stem from lattice distortion including two aspects: (1) The reduction of $d$-spacing. Compared with air atmosphere, hydrogen-etching leads to the decrease of $d$-spacing in anatase (decrease from 3.519 to $3.508 \AA$ and from 3.525 to $3.521 \AA$, Table 1 ) and monoclinic $\mathrm{TiO}_{2}$ (decrease from 6.246 to $6.212 \AA$ and from 6.264 to $6.250 \AA$, Table S3). Meanwhile, hydrogen-etching also gives rise to the positive shift of $2 \theta$, which conforms to the inverse correlation between $d$ and $\theta$ according to Bragg equation $(n \lambda=2 d \sin \theta)$. (2) The decrease in cell parameters. For example, both cell volume $(V)$ of anatase $\left(136.33 \rightarrow 136.27 \AA^{3}\right.$ and $136.09 \rightarrow 135.99 \AA^{3}$, Table 1$)$ and monoclinic $\mathrm{TiO}_{2}$ $\left(285.466 \rightarrow 285.141 \AA^{3}\right.$ and $285.006 \rightarrow 284.252 \AA^{3}$, Table S3) decreased. Hydrogen-etching resulted in the reduction of cell parameters (i.e., the lattice contraction), which is responsible for the reduction of $d$-spacing. Thus, these lattice distortions (i.e., the reduction of cell parameters and $d$-spacing) finally lead to the increase of microstrain. As reported in our previous studies [60,61], the larger the microstrain is, the stronger the interaction between active metals and supports is, and then the higher the surface energy is. Obviously, the stronger interaction and higher surface energy are all in favor of higher catalytic activities. Therefore, hydrogen-etching technology resulted in surface lattice distortion of $\mathrm{TiO}_{2-x}-\mathrm{N}$ support, reflected by a larger microstrain value, which gives rise to higher surface energy and stronger interaction between $\mathrm{Au}$ and $\mathrm{TiO}_{2-x}-\mathrm{N}$ supports and, as a consequence, higher catalytic activities of $\mathrm{Au}-\mathrm{TiO}_{2-x}-\mathrm{N}$.

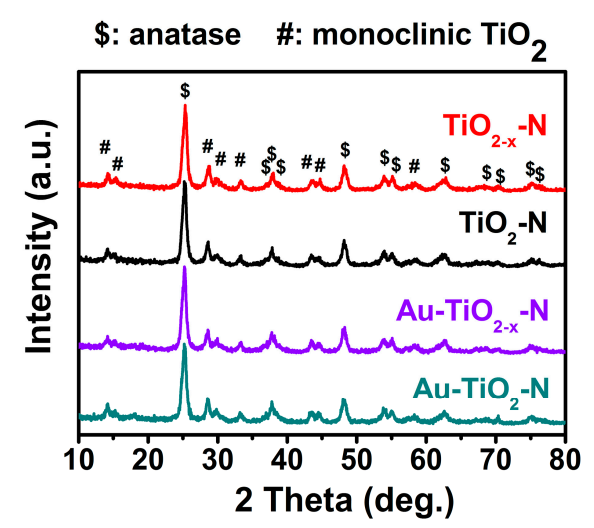

Figure 4. X-ray Diffraction (XRD) patterns of various $\mathrm{TiO}_{2}$ supports and $\mathrm{Au}-\mathrm{TiO}_{2}$ catalysts.

Table 1. Microstructure parameters of various $\mathrm{TiO}_{2}$ supports and $\mathrm{Au}-\mathrm{TiO}_{2}$ catalysts.

\begin{tabular}{|c|c|c|c|c|c|c|c|c|}
\hline \multirow[b]{2}{*}{ Sample } & \multicolumn{8}{|c|}{ Anatase } \\
\hline & $\begin{array}{c}\text { 2theta } \\
\left({ }^{\circ}\right)\end{array}$ & $\begin{array}{l}d \text {-Spacing } \\
\text { (A) }\end{array}$ & $\begin{array}{c}\text { FWHM } \\
\left({ }^{\circ}\right)\end{array}$ & $\begin{array}{c}\text { Crystal } \\
\text { Size }(\mathrm{nm})\end{array}$ & $\begin{array}{l}\text { Microstrain } \\
(\Delta d / d)(\%)\end{array}$ & $a(\AA)$ & $C(\AA)$ & $V\left(\AA^{3}\right)$ \\
\hline $\mathrm{TiO}_{2}-\mathrm{N}$ & 25.287 & 3.519 & 0.564 & 14.52 & 0.600 & 3.7847 & 9.5181 & 136.33 \\
\hline $\mathrm{TiO}_{2-x}-\mathrm{N}$ & 25.365 & 3.508 & 0.597 & 14.63 & 0.617 & 3.7845 & 9.5146 & 136.27 \\
\hline $\mathrm{Au}-\mathrm{TiO}_{2}-\mathrm{N}$ & 25.244 & 3.525 & 0.602 & 14.85 & 0.615 & 3.7838 & 9.5058 & 136.09 \\
\hline $\mathrm{Au}-\mathrm{TiO}_{2-x}-\mathrm{N}$ & 25.274 & 3.521 & 0.609 & 14.89 & 0.625 & 3.7818 & 9.5087 & 135.99 \\
\hline
\end{tabular}

The increase of microstrain can also be proven by the blue-shift and asymmetrical broadening of Raman bands, as presented in Figure 5. These spectra display two sets of Raman bands: (a) anatase $\mathrm{TiO}_{2}$ presents six $(3 \mathrm{Eg}+2 \mathrm{~B} 1 \mathrm{~g}+\mathrm{A} 1 \mathrm{~g})$ bands at about 144, 197, 399, 515, 519 (superimposed with the $515 \mathrm{~cm}^{-1}$ band), and $639 \mathrm{~cm}^{-1}$, respectively [47]; and (b) monoclinic $\mathrm{TiO}_{2}$ presents the most intense mode at $123 \mathrm{~cm}^{-1}$, and other bands superimposed with those of anatase $\mathrm{TiO}_{2}$ (i.e., 145, 161, 172, and 
$196 \mathrm{~cm}^{-1}$ ) [62]. For the strongest band at about $144 \mathrm{~cm}^{-1}$ (external vibration of Ti-O bond), compared with $\mathrm{TiO}_{2}-\mathrm{N}$ and $\mathrm{Au}-\mathrm{TiO}_{2}-\mathrm{N}$, the bands of $\mathrm{TiO}_{2-x}-\mathrm{N}$ and $\mathrm{Au}-\mathrm{TiO}_{2-x}-\mathrm{N}$ shift to higher wavenumber (i.e., blue-shift from 142.5 to $146.1 \mathrm{~cm}^{-1}$ and from 148.6 to $149.6 \mathrm{~cm}^{-1}$, respectively). Raman shift $(\Delta v)$ is the wavenumber difference between Stokes scattered light $\left(v_{\mathrm{s}}\right)$ and incident light $\left(v_{0}\right)$. To explain these phenomena, the calculation of the Raman band is simplified by a physical model-harmonic oscillator. The wavenumber $(v)$ are expressed by Hooke's law as follows:

$$
v\left(\mathrm{~cm}^{-1}\right)=(k / \mu)^{1 / 2} / 2 \pi c
$$

where $c$ is the velocity of light, $k$ is the bond force constant, and $\mu$ is the reduced mass. On the basis of the equation, the blue-shift of Raman bands at $144 \mathrm{~cm}^{-1}$ should be ascribed to the increase of the Ti-O bond force constant $(k)$, which arises from the decrease of the length of Ti-O bond. It shall result in the decrease of cell parameters, which is in very good agreement with XRD Rietveld analysis results (Table 1).
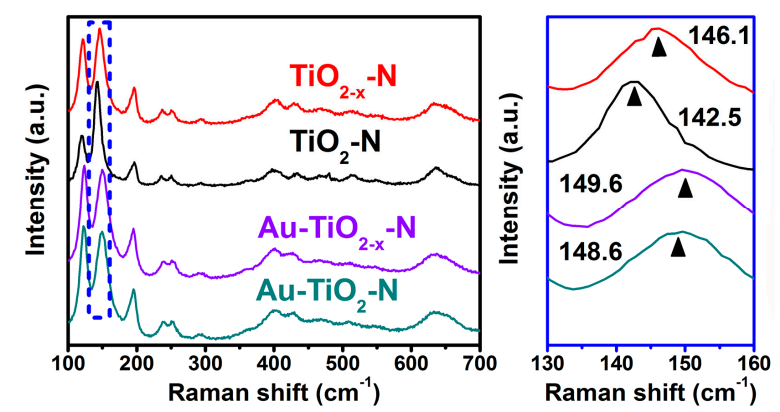

Figure 5. Raman spectra of various $\mathrm{TiO}_{2}$ supports and $\mathrm{Au}-\mathrm{TiO}_{2}$ catalysts.

In addition, as far as asymmetrical broadening is concerned, the $\mathrm{TiO}_{2-x}-\mathrm{N}$ and $\mathrm{Au}-\mathrm{TiO}_{2-x}-\mathrm{N}$ presented asymmetrical broadening bands compared with $\mathrm{TiO}_{2}-\mathrm{N}$ and $\mathrm{Au}-\mathrm{TiO}_{2}-\mathrm{N}$. It has been reported that structural disorder (localized defects associated with oxygen vacancies) was rather responsible for the broadening of the bands observed in black $\mathrm{TiO}_{2}$ [51]. The results indicate that $\mathrm{H}_{2}$ atmosphere resulted in the surface oxygen vacancies due to the reduction of the surface oxygen species, agreeing with the results of $\mathrm{H}_{2}$-TPR (Figure $3 \mathrm{i}$ ).

In other words, during the hydrogen-etching procedure, the reduction of the surface oxygen species resulted in the decrease of the length of Ti-O bond. As a consequence, cell parameters and $d$-spacing are reduced and lattice distortions (i.e., increased microstrain) arise; finally, disorder layers and stable surface oxygen vacancies are formed (Figure S2). Then, Au particles are bound more strongly to surface oxygen vacancies [63], which facilitate the WGS reaction happening at the interface between $\mathrm{Au}$ and oxygen vacancies [41]. Usually, the decrease of surface oxygen species should lead to more surface oxygen vacancies and $\mathrm{Ti}^{3+}$ ions, because of the charge balance $\left(2 \mathrm{Ti}^{4+}+\mathrm{O}^{2-}=2 \mathrm{Ti}^{3+}\right.$ $+V_{0}, V_{\ddot{o}}$ being a doubly ionized oxygen vacancy). The existence of oxygen vacancies and $\mathrm{Ti}^{3+}$ ions can be confirmed by the results of electron paramagnetic resonance (EPR) and X-ray photoelectron spectroscopy (XPS).

EPR measurements were carried out to determine the possible unpaired electrons from hydrogen-etching processes. As shown in Figure 6, $\mathrm{TiO}_{2-x}-\mathrm{N}$ give rise to a EPR signal at $g$-value of 2.004, which should be attributed to surface $\mathrm{Ti}^{3+}[49,51]$ and single electron $\mathrm{O}_{2}{ }^{-}$radical trapped by $\mathrm{O}_{2}$ (from air) adsorbed at oxygen vacancy [64]. However, a very weak signal could be found for $\mathrm{TiO}_{2}-\mathrm{N}$. The results indicate that hydrogen-etching technology results in more surface $\mathrm{Ti}^{3+}$ and oxygen vacancies of $\mathrm{TiO}_{2-x}-\mathrm{N}$. Moreover, $\mathrm{Au}-\mathrm{TiO}_{2-x}-\mathrm{N}$ presents stronger EPR signals than $\mathrm{Au}-\mathrm{TiO}_{2}-\mathrm{N}$. Thus, surface $\mathrm{Ti}^{3+}$ and oxygen vacancies should be highly stable, in spite of immersion in water during the preparation process of Au catalysts. Furthermore, it was found that the color of blue black $\mathrm{TiO}_{2-x}-\mathrm{N}$ did not change in air over several months. 


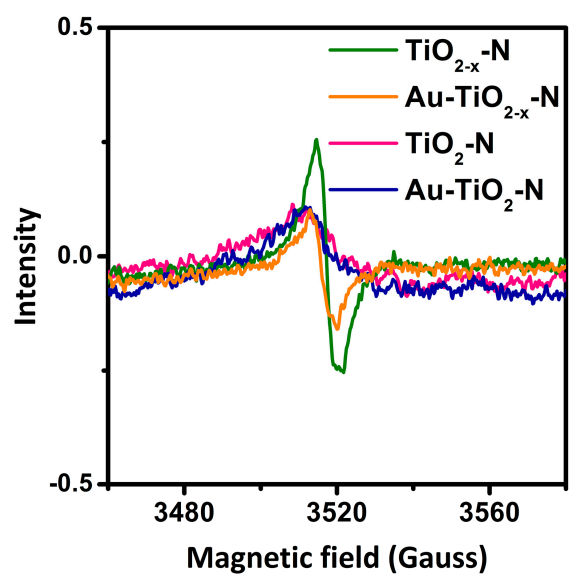

Figure 6. The electron paramagnetic resonance (EPR) spectra of various $\mathrm{TiO}_{2}$ supports and $\mathrm{Au}-\mathrm{TiO}_{2}$ catalysts.

As presented in Figure S1a,b, XPS spectra of all samples show identical elements, indicating that hydrogen-etching technology does not introduce other impurities. For Ti 2p spectra (Figure 7a), compared with the $\mathrm{TiO}_{2}-\mathrm{N}$ and $\mathrm{Au}-\mathrm{TiO}_{2}-\mathrm{N}$ calcined in air, the binding energy of $\mathrm{TiO}_{2-x}-\mathrm{N}$ and $\mathrm{Au}-\mathrm{TiO}_{2-x}-\mathrm{N}$ shift to a low energy range, which indicates the increase in electron density around $\mathrm{Ti}$ atoms [64]. Thus, a certain amount of $\mathrm{Ti}^{3+}$ appears in $\mathrm{TiO}_{2-x}-\mathrm{N}$ and $\mathrm{Au}-\mathrm{TiO}_{2-x}-\mathrm{N}$, in accordance with EPR results.

The $\mathrm{O} 1$ s peaks can be fitted into two peaks at about 529.2 and $531 \mathrm{eV}$, which are due to Ti-O and surface $\mathrm{OH}$ species, respectively. As shown in Figure $7 \mathrm{~d}-\mathrm{g}$, the $\mathrm{O} 1 \mathrm{~s}$ spectra show that $\mathrm{TiO}_{2-x}-\mathrm{N}$ and $\mathrm{Au}-\mathrm{TiO}_{2-x}-\mathrm{N}$ has much less surface $\mathrm{OH}$ species than does $\mathrm{TiO}_{2}-\mathrm{N}$ and $\mathrm{Au}-\mathrm{TiO}_{2}-\mathrm{N}$, respectively. Meanwhile, for the ratio of $\mathrm{O}$ to Ti atoms, the ratios of $\mathrm{TiO}_{2-x}-\mathrm{N}$ and $\mathrm{Au}-\mathrm{TiO}_{2-x}-\mathrm{N}$ are all less than two, whereas the ratios of $\mathrm{TiO}_{2}-\mathrm{N}$ and $\mathrm{Au}-\mathrm{TiO}_{2}-\mathrm{N}$ are all greater than two, indicating that $\mathrm{TiO}_{2-x}-\mathrm{N}$ and $\mathrm{Au}-\mathrm{TiO}_{2-x}-\mathrm{N}$ present a nonstoichiometric titanium dioxide with the shortage of oxygen atoms. In short, the results indicate that the decrease of surface $\mathrm{OH}$ species should be due to $\mathrm{H}_{2}$ reduction during the hydrogen-etching technology [52], with the forming of surface oxygen vacancies, consistent with the results of TEM, $\mathrm{H}_{2}-\mathrm{TPR}$, XRD, Raman and EPR.

For $\mathrm{Au} 4 \mathrm{f}$ spectra, $\mathrm{Au}-\mathrm{TiO}_{2}-\mathrm{N}$ and $\mathrm{Au}-\mathrm{TiO}_{2-x}-\mathrm{N}$ present almost equal amount of $\mathrm{Au}$ (Figure $7 \mathrm{~b}, \mathrm{c}$ ). Both $\mathrm{Au}-\mathrm{TiO}_{2}-\mathrm{N}$ and $\mathrm{Au}-\mathrm{TiO}_{2-x}-\mathrm{N}$ present the different ratios of metallic $\mathrm{Au}^{0}$ and $\mathrm{Au}^{3+}$ species. $\mathrm{Au}-\mathrm{TiO}_{2-x}-\mathrm{N}$ presents more metallic $\mathrm{Au}^{0}$ species (46.6\%) than $\mathrm{Au}-\mathrm{TiO}_{2}-\mathrm{N}(37.9 \%)$. Considering that $\mathrm{HAuCl}_{4}\left(\mathrm{Au}^{3+}\right)$ was used as gold source, we inferred that the obtained metallic $\mathrm{Au}^{0}$ species should be reduced by surface oxygen vacancies of support with the charge transfer from oxygen vacancies to $\mathrm{Au}$ particles [65]. Because the surface oxygen vacancies of $\mathrm{TiO}_{2-x}-\mathrm{N}$ are far richer than those of $\mathrm{TiO}_{2}-\mathrm{N}$, during the deposition of gold species (i.e., $\left.\mathrm{Au}(\mathrm{OH})_{3}\right)$, the amount of metallic $\mathrm{Au}^{0}$ species supported on the $\mathrm{TiO}_{2-x}-\mathrm{N}$ is far larger than on $\mathrm{TiO}_{2}-\mathrm{N}$. The metallic $\mathrm{Au}^{0}$ species have been regarded as a requisite for a high $\mathrm{CO}$ oxidation and WGS activity of $\mathrm{Au} / \mathrm{TiO}_{2}$ catalysts $[11,12,66,67]$; thus, $\mathrm{Au}-\mathrm{TiO}_{2-x}-\mathrm{N}$ present higher catalytic activities. Therefore, the difference in their catalytic activities mainly depends on the difference in Au valence, which is influenced by the amount of support surface oxygen vacancies. 

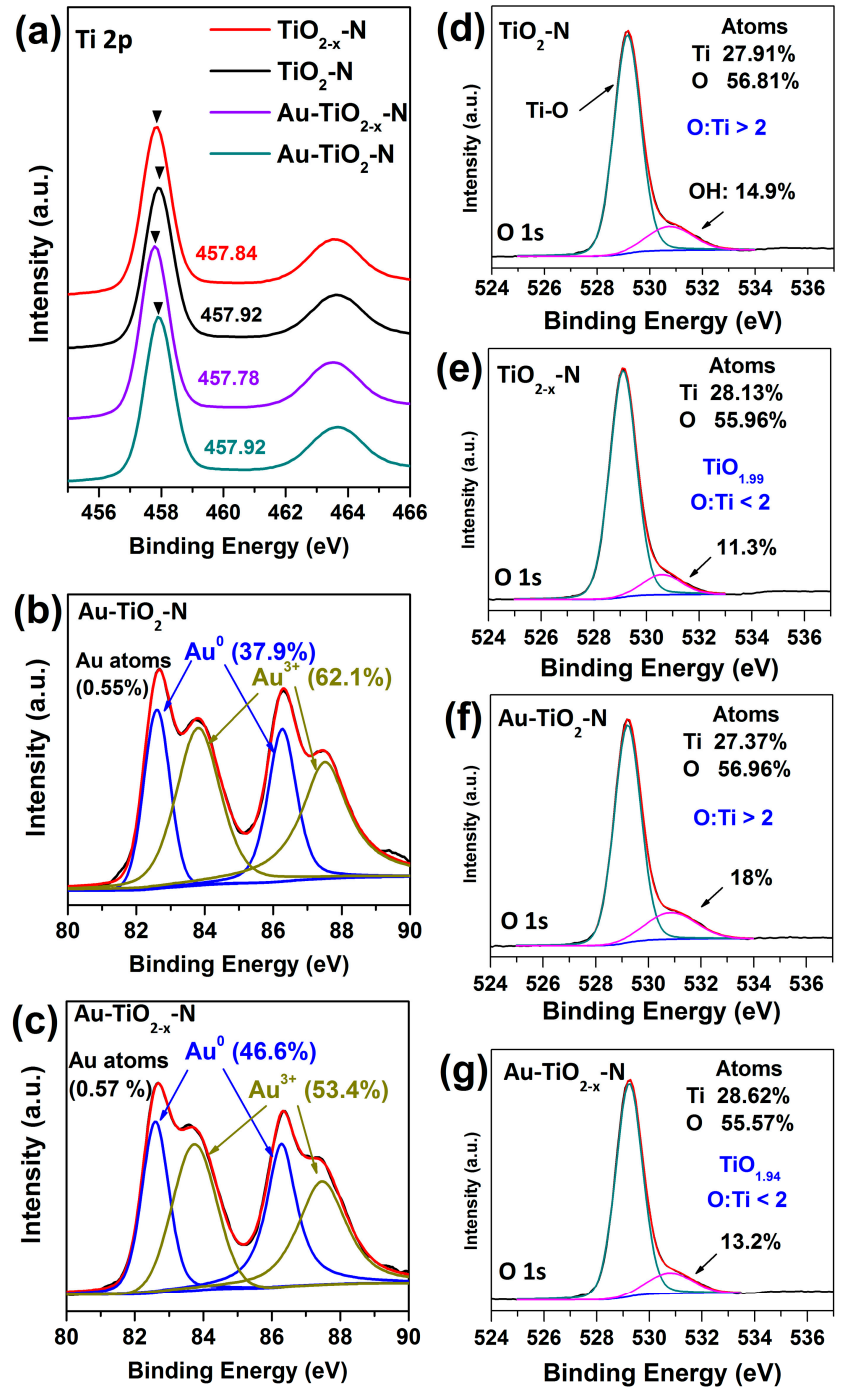

Figure 7. XPS spectra of various $\mathrm{TiO}_{2}$ supports and $\mathrm{Au}-\mathrm{TiO}_{2}$ catalysts (a) $\mathrm{Ti} 2 \mathrm{p} ;(\mathbf{b}, \mathbf{c}) \mathrm{Au} 4 \mathrm{f} ;(\mathbf{d}-\mathbf{g}) \mathrm{O} 1 \mathrm{~s}$.

\subsection{Optoelectronic Properties}

As shown in Figure 8a, the $\mathrm{TiO}_{2-x}-\mathrm{N}$ and $\mathrm{Au}-\mathrm{TiO}_{2-x}-\mathrm{N}$ exhibit decreased $E_{g}$ value (3.09 and $2.97 \mathrm{eV}$ ) compared with $\mathrm{TiO}_{2}-\mathrm{N}$ and $\mathrm{Au}-\mathrm{TiO}_{2}-\mathrm{N}(3.15$ and $3.05 \mathrm{eV})$. Then, valence band spectra of $\mathrm{TiO}_{2}-\mathrm{N}$ and $\mathrm{TiO}_{2-x}-\mathrm{N}$ were measured, and the valence band maximum (VBM) almost locates a similar value (1.99 eV below the Fermi energy, Figure 8b), consistent with the reported results [53]. Due to the same VBM, the above-mentioned decrease of $E_{g}$ value should be ascribed to the decrease of the conduction band minimum (CBM). The $\mathrm{CBM}$ of $\mathrm{TiO}_{2-x}-\mathrm{N}(-1.1 \mathrm{eV}$ above the Fermi energy) locates lower than that of $\mathrm{TiO}_{2}-\mathrm{N}(-1.16 \mathrm{eV}$ above the Fermi energy). 

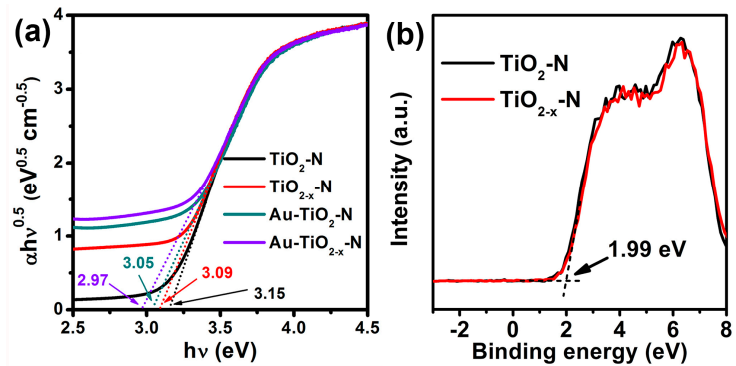

Figure 8. (a) The optical absorption edges and (b) XPS valence band spectra of various $\mathrm{TiO}_{2}$ supports and $\mathrm{Au}-\mathrm{TiO}_{2}$ catalysts.

Photoluminescence (PL) spectra were also measured to understand the behaviour of light-generated electrons and holes since PL emission is a result of the recombination of the free carriers. As shown in Figure 9a, the shapes of the emission spectra of different samples are similar. Importantly, the PL peak intensities of $\mathrm{TiO}_{2-x}-\mathrm{N}$ and $\mathrm{Au}-\mathrm{TiO}_{2-x}-\mathrm{N}$ are much lower than those of $\mathrm{TiO}_{2}-\mathrm{N}$ and $\mathrm{Au}-\mathrm{TiO}_{2}-\mathrm{N}$, respectively. This observation indicates that the $\mathrm{TiO}_{2-x}-\mathrm{N}$ and $\mathrm{Au}-\mathrm{TiO}_{2-x}-\mathrm{N}$ have relatively low recombination rates of electrons and holes.
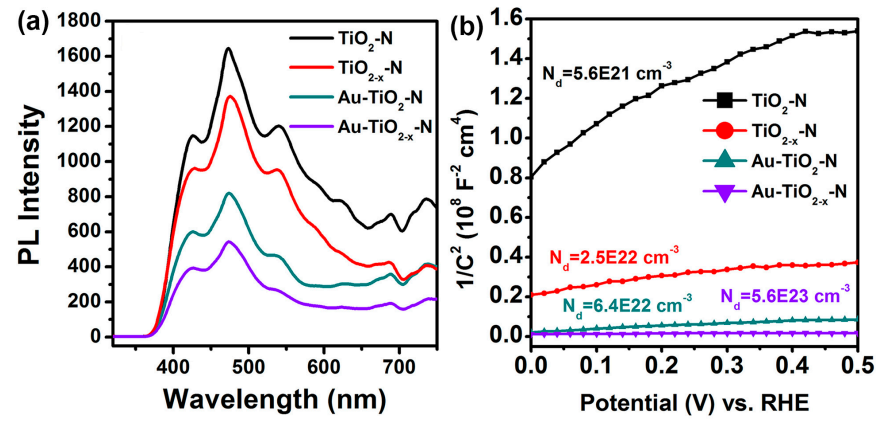

Figure 9. (a) Photoluminescence spectra and (b) Mott-Schottky plots collected at a frequency of $10 \mathrm{kHz}$ in the dark of various $\mathrm{TiO}_{2}$ supports and $\mathrm{Au}-\mathrm{TiO}_{2}$ catalysts.

Additionally, electrochemical impedance measurements on the various $\mathrm{TiO}_{2}$ supports and $\mathrm{Au}-\mathrm{TiO}_{2}$ catalysts were performed to investigate the effect of hydrogen-etching on their electronic properties. All samples show a positive slope in the Mott-Schottky plots (Figure 9b), as expected for $n$-type semiconductor. Carrier densities of these samples were calculated from the slopes of Mott-Schottky plots using the equation

$$
N_{\mathrm{d}}=\left(2 / e_{0} \varepsilon \varepsilon_{0}\right)\left[d\left(1 / C^{2}\right) / \mathrm{d} V\right]^{-1}
$$

where $e_{0}$ is the electron charge, $\varepsilon$ is the dielectric constant of $\mathrm{TiO}_{2}(\varepsilon=170)$ [68], $\varepsilon_{0}$ is the permittivity of vacuum $\left(8.85 \times 10^{-12} \mathrm{~F} / \mathrm{m}\right), N_{\mathrm{d}}$ is the electron density, and $V$ is the applied bias at the electrode. The calculated electron densities of the $\mathrm{TiO}_{2}-\mathrm{N}, \mathrm{TiO}_{2-x}-\mathrm{N}, \mathrm{Au}-\mathrm{TiO}_{2}-\mathrm{N}$ and $\mathrm{Au}-\mathrm{TiO}_{2-x}-\mathrm{N}$ were $5.6 \times 10^{21} \mathrm{~cm}^{-3}, 2.5 \times 10^{22} \mathrm{~cm}^{-3}, 6.4 \times 10^{22} \mathrm{~cm}^{-3}$ and $5.6 \times 10^{23} \mathrm{~cm}^{-3}$, respectively. In other words, $\mathrm{TiO}_{2-x}-\mathrm{N}$ and $\mathrm{Au}-\mathrm{TiO}_{2-x}-\mathrm{N}$ show substantially smaller slopes of Mott-Schottky plots compared to $\mathrm{TiO}_{2}-\mathrm{N}$ and $\mathrm{Au}-\mathrm{TiO}_{2}-\mathrm{N}$ samples, suggesting an increase of electron densities $[54,68]$. The enhanced electron density is due to the increased oxygen vacancies, which are known as an electron donor for $\mathrm{TiO}_{2}$ [68]. The increased electron density improves the charge transport in $\mathrm{TiO}_{2-x}-\mathrm{N}$ and $\mathrm{Au}-\mathrm{TiO}_{2-x}-\mathrm{N}$. Moreover, the increased electron density is expected to shift the Fermi level of $\mathrm{TiO}_{2}$ toward the conduction band, which facilitates the charge separation at the semiconductor/metal interface. The enhanced charge separation and transportation are in very good agreement with the results of PL (Figure 9a). 


\section{Discussion}

\section{Proposed Electron Flow Process}

Finally, a question arises: what causes the differences in WGS catalytic activities over $\mathrm{Au}-\mathrm{TiO}_{2-x}-\mathrm{N}$ and $\mathrm{Au}-\mathrm{TiO}_{2}-\mathrm{N}$ ? To answer this question, it is essential to discuss the reaction mechanism. From the view of the traditional WGS reaction mechanism, $\mathrm{Au}-\mathrm{TiO}_{2}$ has been considered as a bifunctional catalyst [39-41]: CO adsorbs on the gold nanoparticles and the adsorption and dissociation of water takes place on the oxide or oxide-metal interfaces. Recently, Sastre et al. [69] reported the photocatalytic version of WGS reaction over $\mathrm{Au}-\mathrm{TiO}_{2}$ catalysts. They proposed a possible photocatalytic mechanism: under visible light irradiation the surface plasmon band of Au nanoparticles will be excited and will inject electrons (-) to the conduction band of the $\mathrm{TiO}_{2}$, which facilitates water reduction to hydrogen, and the holes (+) remaining on Au nanoparticles will be responsible for the oxidation of adsorbed $\mathrm{CO}$. Furthermore, "hot-electron flow" can be formed between metal-oxide interfaces during exothermic chemical processes, and the "hot-electron flow" plays a key role in determining the catalytic activity of CO oxidation [46,56-58]. Accordingly, correlating traditional and photocatalytic WGS reaction mechanisms with the optoelectronic properties, we try to understand the WGS pathway from the view of electron flow processes, as shown in Figure 10.

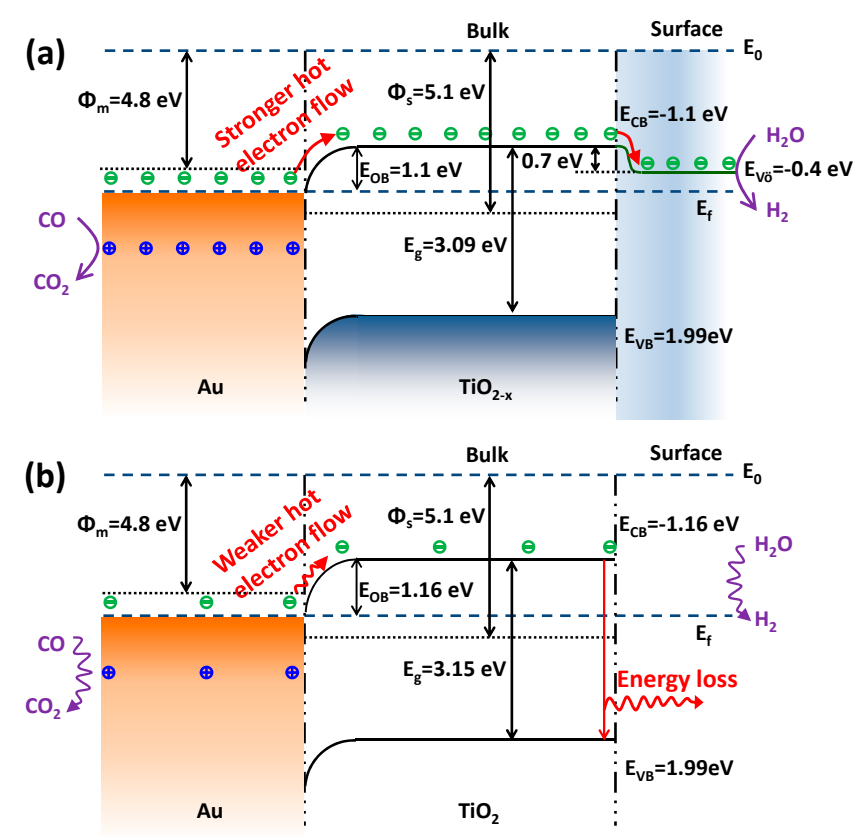

Figure 10. Proposed electron flow process of $\mathrm{Au}-\mathrm{TiO}_{2-x}(\mathbf{a})$ and $\mathrm{Au}-\mathrm{TiO}_{2}$ (b) for the WGS reaction based on hot-electron flow. $\Phi_{\mathrm{m}}$ : work function of metal; $\Phi_{\mathrm{s}}$ : work function of semiconductor; $E_{\mathrm{f}}$ : Fermi level; $E_{0}$ : vacuum level; $E_{\mathrm{OB}}$ : Ohmic barrier, $V_{\mathrm{O}}$ : oxygen vacancy; $E_{\mathrm{CB}}$ : conduction band; $E_{\mathrm{VB}}$ : valence band.

At first, more surface oxygen vacancies of $\mathrm{TiO}_{2-x}-\mathrm{N}$ lead to the fact that gold of $\mathrm{Au}-\mathrm{TiO}_{2-x}-\mathrm{N}$ mainly exists as metallic $\mathrm{Au}^{0}$ species (XPS results). As shown in Figure 10a, since the work function of metal $\mathrm{Au}\left(\Phi_{\mathrm{m}}=4.8 \mathrm{eV}\right)$ is smaller than that of semiconductor $\mathrm{TiO}_{2}\left(\Phi_{\mathrm{s}}=5.1 \mathrm{eV}\right)[70]$, the electrons can diffuse from the metal into the semiconductor when the two phases are in contact [71,72]. This electron transfer was called "hot-electron flow" [56,57,73-75] or "chemicurrent" [76-78], which usually happened in exothermic catalytic reactions [56,57,73-75] and low-energy reactions [74] or even nonthermal directions [75]. For example, it has been reported that electron excitation was also involved in atomic/molecular adsorption processes $[73,77,78]$. The chemicurrent concept was first applied by Nienhaus et al. to observe the generation of hot electrons and holes during chemisorption 
of monatomic gas particles on the $\mathrm{Ag} / \mathrm{n}-\mathrm{Si}$ nanodiodes [78]. In this case, $\mathrm{CO}$ can chemisorb on coordinately unsaturated Au sites, and the heat of adsorption was reported to be in the range of $52.3-76.6 \mathrm{~kJ} / \mathrm{mol}[79,80]$. Meanwhile, the electron transfer can be promoted by the energies from the WGS reaction heat (molar enthalpy of reaction at $\left.200{ }^{\circ} \mathrm{C}:-41.7 \mathrm{~kJ} / \mathrm{mol}\right)$ and $/$ or external heat $\left(Q_{A u}=\right.$ $4.4 \mathrm{~kJ} / \mathrm{mol}$ at $200^{\circ} \mathrm{C}$ ). Thus, energetic electrons can be powered by the energy of $98.4-122.7 \mathrm{~kJ} / \mathrm{mol}$ $(1.02-1.27 \mathrm{eV})$, which is enough for electron transfer from metal Au to $\mathrm{TiO}_{2-x}$ support. Hence, the gold carries positive charge and $\mathrm{TiO}_{2-x}$ carries negative charge. Gold species with a positive charge $(+)$ are similar to the $\mathrm{Au}-(\mathrm{OH})_{x}$ species with a mildly oxidized state $\left(\mathrm{Au}^{\delta+}\right)$, which were identified as active gold sites [10,81]. For example, Hammer et al. investigated the valence shifts in $\mathrm{Au}$ of $\mathrm{AuTiO}_{2}$ catalysts in the WGS reaction using in situ X-ray absorption spectroscopy (XAS) [81]. When the feed is changed from inert to WGS reaction composition, there are some extent valence shifts in gold from $\mathrm{Au}^{0}$ to $\mathrm{Au}^{+}$. It means that $\mathrm{Au}^{0}$ can give the electrons to the near $\mathrm{TiO}_{2}$ supports under the WGS reaction conditions. Meanwhile, after the WGS reaction, the positive $\mathrm{Au}^{+}$can go back to metallic $\mathrm{Au}^{0}$. Therefore, the formation of the mildly oxidized gold species with positive charge (+) actually happen under the WGS reaction conditions because of the electron transmission from gold to $\mathrm{TiO}_{2-x}$ support. In subsequent steps, the mildly oxidized gold species with positive charge $(+)$ can easily react with electronic donors (adsorbed $\mathrm{CO}$ reactant) to further form the $\mathrm{CO}_{2}$ product.

In addition, the energy bands $\left(E_{\mathrm{CB}}\right.$ and $\left.E_{\mathrm{VB}}\right)$ of the semiconductor are bent downwards and form their new Fermi levels $[56,71,72]$, which forms the Ohmic barrier $\left(E_{\mathrm{OB}}\right.$, i.e., energy difference between metal $\mathrm{Au}$ and the bent $E_{\mathrm{CB}}$ of the semiconductor). As mentioned in the paragraph above, energetic electrons with energy of $98.4-122.7 \mathrm{~kJ} / \mathrm{mol}(1.02-1.27 \mathrm{eV})$ are enough to move across the Ohmic barrier $\left(E_{\mathrm{OB}}=1.1 \mathrm{eV}\right.$, Figure 10), suggesting that the electrons can transfer to the conduction band of the semiconductor $\mathrm{TiO}_{2}$ to form hot-electron flow. According to the results of Figure 8, the Ohmic barrier $\left(E_{\mathrm{OB}}=1.1 \mathrm{eV}\right)$ of $\mathrm{Au}-\mathrm{TiO}_{2-x}-\mathrm{N}$ is smaller than that of $\mathrm{Au}-\mathrm{TiO}_{2}-\mathrm{N}\left(E_{\mathrm{OB}}=1.16 \mathrm{eV}\right)$. Thus, compared with the excited electrons in $\mathrm{Au}-\mathrm{TiO}_{2}-\mathrm{N}$, the excited electrons in $\mathrm{Au}-\mathrm{TiO}_{2-x}-\mathrm{N}$ can more easily move across a lower Ohmic barrier and form a stronger "hot-electron flow". Because oxygen vacancies are considered as electron traps [68], the "hot-electrons" of conduction band further transfer to the oxygen vacancies, which locate at about $0.7 \mathrm{eV}$ below the conduction band minimum [51]. Thus, the surface oxygen vacancies of $\mathrm{TiO}_{2-x}-\mathrm{N}$ and $\mathrm{Au}-\mathrm{TiO}_{2-x}-\mathrm{N}$ suppress the recombination of electron from conduction band to valence band. It is reflected in lower intensities of $\mathrm{PL}$ of $\mathrm{TiO}_{2-}-\mathrm{N}$ and $\mathrm{Au}-\mathrm{TiO}_{2-x}-\mathrm{N}$ (Figure 9a). The abundant "hot-electrons" located in oxygen vacancies can be easily trapped by electronic acceptors $\left(\mathrm{H}_{2} \mathrm{O}\right.$ reactant) to form the $\mathrm{H}_{2}$ product. In other words, due to the lower Ohmic barrier and more surface oxygen vacancies, $\mathrm{Au}-\mathrm{TiO}_{2-x}-\mathrm{N}$ presents a higher transmission efficiency of "hot-electron flow", which are correlated with higher electron density based on the results of Mott-Schottky plots (Figure 9b), so as to enhance the WGS catalytic activity. On the contrary, for $\mathrm{Au}-\mathrm{TiO}_{2}-\mathrm{N}$ catalyst (Figure 10b), a larger forbidden band gap leads to a bigger Ohmic barrier, which makes a weaker "hot-electron flow". Meanwhile, due to few surface oxygen vacancies, few formed "hot-electrons" easily jump from conduction band to valence band and make energy loss. Therefore, $\mathrm{Au}-\mathrm{TiO}_{2}-\mathrm{N}$ catalyst presents a lower WGS catalytic activity.

From the above discussion, a stronger "hot-electron flow" effect of $\mathrm{Au}-\mathrm{TiO}_{2-x}-\mathrm{N}$ should be attributed to the lower Ohmic barrier (i.e., decrease of the forbidden band gap) and abundant surface oxygen vacancies (i.e., higher transmission efficiency of "hot-electron flow"). The stronger hot-electron flow can easily boost the reaction rate [73,74]. Considering that $\mathrm{Au}-\mathrm{TiO}_{2-x}-\mathrm{N}$ catalyst showed a bigger TOF (Figure 1b), we concluded that the bigger TOF mainly stems from a stronger "hot-electron flow", in very good agreement with the conclusions of some studies [73,74]. In addition, $\mathrm{Au}-\mathrm{TiO}_{2-x}-\mathrm{N}$ presented better stability than $\mathrm{Au}-\mathrm{TiO}_{2}-\mathrm{N}$ (Figure 1c). It has been reported that partially reduced support (with oxygen vacancies) is the best substrate to anchor Au particles [82]. Therefore, the results further prove that oxygen vacancies can anchor Au particles to avoid aggregation of Au particles and the deactivation of WGS catalysts. 
Certainly, the present results do not provide direct mechanistic information on the effect of hydrogen-etched $\mathrm{TiO}_{2-x}$ support on the WGS activity of $\mathrm{Au}-\mathrm{TiO}_{2-x}$ catalysts. A deeper understanding on the reaction mechanism of the WGS reaction over the $\mathrm{Au}-\mathrm{TiO}_{2-x}$ catalyst needs detailed studies of elementary steps and intermediate productions. Nevertheless, it is also interesting to understand WGS reaction pathways from the new standpoint of electron flow processes. In this sense, the involved hydrogen-etching method resulting in abundant stable surface oxygen vacancies can be extended to other supported catalysts (e.g., $\mathrm{CeO}_{2}$ and $\mathrm{ZrO}_{2}$ based catalysts) for WGS reaction or other thermocatalytic reactions.

\section{Materials and Methods}

\subsection{Preparation of White $\mathrm{TiO}_{2}-\mathrm{N}$ and Blue-Black $\mathrm{TiO}_{2}-x-\mathrm{N}$ Supports}

$\mathrm{TiO}_{2}$ nanoribbons were prepared by alkaline hydrothermal route as reported in our previous works [83]. $1.6 \mathrm{~g}$ of $\mathrm{Ti}\left(\mathrm{OC}_{4} \mathrm{H}_{9}\right)_{4}, 17 \mathrm{~g}$ of $\mathrm{NaOH}$, and $40 \mathrm{~mL}$ of distilled water were added into a $50 \mathrm{~mL}$ of Teflon-lined autoclave and mixed homogeneously. Then, they were reacted at $200{ }^{\circ} \mathrm{C}$ for $48 \mathrm{~h}$ in an electrical oven. The obtained sodium titanate $\left(\mathrm{Na}_{2} \mathrm{Ti}_{3} \mathrm{O}_{7}\right)$ nanoribbon was rinsed with distilled water, acidified in $0.1 \mathrm{M} \mathrm{HNO}_{3}$ overnight, and dried at $100{ }^{\circ} \mathrm{C}$. After that, the protonated titanate $\left(\mathrm{H}_{2} \mathrm{Ti}_{3} \mathrm{O}_{7}\right)$ was calcined at $550{ }^{\circ} \mathrm{C}$ for $4 \mathrm{~h}$ in air and $\mathrm{H}_{2}$ atmospheres, the white $\mathrm{TiO}_{2}$ nanoribbon $\left(\mathrm{TiO}_{2}-\mathrm{N}\right)$ and the corresponding blue-black $\mathrm{TiO}_{2}$ nanoribbon $\left(\mathrm{TiO}_{2-x}-\mathrm{N}\right)$ were obtained, respectively.

\subsection{Preparation of $\mathrm{Au}-\mathrm{TiO}_{2}-\mathrm{N}$ and $\mathrm{Au}-\mathrm{TiO}_{2}-x-\mathrm{N}$ Catalysts}

Gold supported on the white $\mathrm{TiO}_{2}-\mathrm{N}$ and blue-black $\mathrm{TiO}_{2-x}-\mathrm{N}$ catalysts with Au content of 4 wt \% were fabricated by deposition-precipitation. The synthetic route was described as follows: $0.7 \mathrm{~g}$ of the above as-prepared supports was dispersed in $200 \mathrm{~mL}$ of deionized water under sonication for $30 \mathrm{~min}$. Then, $60 \mathrm{~mL}$ of $0.0025 \mathrm{~mol} / \mathrm{L} \mathrm{HAuCl}_{4}$ solution and an appropriate amount of $0.05 \mathrm{~mol} / \mathrm{L} \mathrm{NH}_{3} \cdot \mathrm{H}_{2} \mathrm{O}$ solution were simultaneously added into the above suspension. During this process, the $\mathrm{pH}$ value and the temperature of the solution were held at $10 \pm 1$ and $80^{\circ} \mathrm{C}$, respectively. The precipitate was aged at this temperature for another $5 \mathrm{~h}$, washed with deionized water until $\mathrm{pH}$ value of supernatant is neutral, dried at $105^{\circ} \mathrm{C}$ for $12 \mathrm{~h}$ in air. The obtained samples were directly used as catalyst and denoted as $\mathrm{Au}-\mathrm{TiO}_{2}-\mathrm{N}$ or $\mathrm{Au}-\mathrm{TiO}_{2-x}-\mathrm{N}$.

\subsection{Evaluation of Catalytic Activity and Stability}

The catalytic activities and stabilities of the catalysts for WGS reaction were tested in a fixed bed reactor at atmospheric pressure. $0.1 \mathrm{~g}$ of catalysts (60-80 mesh) were placed on quartz wool layer in a quartz glass tube (inner diameter $=7 \mathrm{~mm}$ ). The reaction temperature was monitored by two thermocouples, which are inserted into the catalyst bed and the reactor wall, respectively. The experiment was directly performed without any pre-reduction. The flow of dry feed gas $(12.5 \% \mathrm{CO}$ and $87.5 \% \mathrm{~N}_{2}$ ) was at $50 \mathrm{~mL} / \mathrm{min}$. The ratio of vapor to dry feed gas was maintained at $1: 1$. The residual water of the outlet was removed by a condenser before entering a gas chromatography (GC 2060) equipped with a thermal conductivity detector (TCD). The by-product (e.g., methane) was not checked in the temperature range investigated. The catalytic activity was measured from 200 to $600{ }^{\circ} \mathrm{C}$, staying for approximately $1 \mathrm{~h}$ at each temperature. Then, an isothermal test $\left(600{ }^{\circ} \mathrm{C}\right)$ was run for about $32 \mathrm{~h}$ to investigate the deactivation.

The conversion of $\mathrm{CO}$ was defined as: $X_{\mathrm{CO}}(\%)=\left(1-V^{\prime}{ }_{\mathrm{CO}} / V_{\mathrm{CO}}\right) \times 100 \% /\left(1+V^{\prime} \mathrm{CO}\right)[60,61]$, where $V_{\mathrm{CO}}$ and $V^{\prime} \mathrm{CO}$ are the inlet and outlet $\mathrm{CO}$ content of dry gas due to condensation, respectively.

To make a more realistic comparison of catalytic activities, turnover frequencies (TOFs) were measured in the kinetic region with negligible heat and mass-transfer effects. Differential conditions were maintained by keeping CO conversion below $10 \%$. This was accomplished by decreasing the catalyst weight and adjusting the flow rate of feed gas $\left(12.5 \% \mathrm{CO}\right.$ and $\left.87.5 \% \mathrm{~N}_{2}\right)$. Meanwhile, the catalyst was diluted with low surface area quartz sands in order to maintain a constant bed height 
and volume. The measurements were conducted at $10{ }^{\circ} \mathrm{C}$ intervals for temperatures of $200-240{ }^{\circ} \mathrm{C}$. The TOF $\left(\mathrm{s}^{-1}\right)$ was calculated shown as [84]:

$$
\operatorname{TOF}\left(\mathrm{s}^{-1}\right)=\frac{\text { mol of CO converted }}{\text { mol of } A u \times \text { time }(s)}=\frac{\left(V_{C O}-V_{C O}^{\prime}\right) \times F}{W \times A u \text { loading } \times D / M_{A u}}
$$

where $F$ is the total flow rate $\left(\mu \mathrm{mol} \mathrm{s}^{-1}\right), W$ the mass of catalyst $(\mathrm{g})$, Au loading (wt $\%$ ) was measured by inductively coupled plasma optical emission spectrometer (ICP-OES), gold dispersion $(D)$ was estimated from TEM results (Supplementary Materials), $M_{A u}$ is the molar mass of $\mathrm{Au}(197 \mathrm{~g} / \mathrm{mol})$.

\subsection{Characterization}

Powder XRD patterns of the as-synthesized samples were recorded by a PANalytical $X^{\prime}$ pert Pro diffractometer (PANalytical, Almelo, The Netherlands) equipped with $\mathrm{Cu}-\mathrm{K} \alpha(\lambda=0.1541 \mathrm{~nm})$ radiation ( $\mathrm{X}^{\prime}$ Celerator detector) operating at $40 \mathrm{kV}$ and $40 \mathrm{~mA}$ with a scanning rate of $0.12 \% / \mathrm{min}$. For Rietveld analysis, the XRD pattern of standard reference material (NIST 640A silicon), which is a material with no microstrain nor size broadening, was measured from $10^{\circ}$ to $140^{\circ}$ on the same instrument with the same experimental parameters. The patterns of the standard and experimental samples were fitted with a pseudo-Voigt function (PVF), which were carried out with X'pert highscore plus software. The actual Au loading in each catalyst was measured by ICP-OES using a Varian 710-ES analyzer (Varian, Englewood, CO, USA). The morphology was examined by using field emission scanning electron microscopy (SEM, Hitachi S-4800, Hitachi, Ibaraki, Japan) and transmission electron microscopy (TEM, JEM-2100, JEM Ltd., Tokyo, Japan). Gold cluster size distributions were measured using >200 particles for each sample to determine surface-averaged cluster diameters $\left(d_{\text {TEM }}\right)[84]$ :

$$
d_{\mathrm{TEM}}=\frac{\sum n_{i} d_{i}^{3}}{\sum n_{i} d_{i}^{2}}
$$

where $n_{i}$ is the number of clusters with diameter $d_{i}$. Metal dispersions $(D)$, defined as the fraction of $\mathrm{Au}$ atoms exposed at cluster surfaces, and were estimated from $d_{\mathrm{TEM}}$ :

$$
D=6 \frac{v_{m} / a_{m}}{d_{\mathrm{TEM}}}
$$

where $v_{m}$ is the bulk atomic density of $\mathrm{Au}\left(16.49 \times 10^{-3} \mathrm{~nm}^{3}\right)$ and $a_{m}$ is the area occupied by an $\mathrm{Au}$ atom $\left(8.75 \times 10^{-2} \mathrm{~nm}^{2}\right)$ on a polycrystalline surface [84].

Raman spectra were collected at room temperature on a Renishaw Invia Plus instrument (Renishaw, Gloucetershire, UK) using a semiconductor laser as an illumination source (532 $\mathrm{nm}$ ). The electron paramagnetic resonance (EPR) spectra were collected using a Bruker EMX-8 spectrometer (Bruker Instruments Inc., Rheinstetten, Germany) at room temperature. The settings were center field, $3510 \mathrm{G}$; microwave frequency, $9.859 \mathrm{GHz}$; and power, $10.02 \mathrm{~mW}$. The X-ray photoelectron spectroscopy (XPS) measurements were performed on a VG ESCALAB 250 spectrophotometer (Thermo Electron Co., Eastern Grinstead, UK) with Al Ka radiation (1486.6 eV), operating at $15 \mathrm{kV} \times 10 \mathrm{~mA}$, in FAT mode (Fixed Analyser Transmission), with a pass energy of $30 \mathrm{eV}$ for regions ROI and $100 \mathrm{eV}$ for survey. The base pressure of the main chamber was kept at about $1 \times 10^{-9} \mathrm{mbar}$. Each sample was first placed in a copper holder mounted on a sample-rod in the pretreatment chamber of the spectrometer, and it was then outgassed at $100{ }^{\circ} \mathrm{C}$ for $1 \mathrm{~h}$ before being transferred to the analysis chamber. A flood gun was always used for charge compensation. The spot size is $500 \mu \mathrm{m}$ and each high-resolution spectrum was scanned for ten times with an energy step size of $0.05 \mathrm{eV}$. All binding energies (BE) were calibrated by using that of $\mathrm{C} 1 \mathrm{~s}(284.5 \mathrm{eV})$. The peaks obtained after a Shirley background subtraction were fitted to Lorentzian-Gaussian curves using a public software XPSPEAK (Version 4.1, programmed by R. Kwok, Chinese University of Hong Kong, China). 
Temperature-programmed reduction (TPR) measurements were carried out on an AutoChem 2910 apparatus equipped with a thermal conductivity detector (TCD) (Micromeritics, Norcross, GA, USA) for analysis. $50 \mathrm{mg}$ of each sample was purged with high purity argon gas at $110^{\circ} \mathrm{C}$ for $1 \mathrm{~h}$, and cooled under the same gas flow to room temperature, finally reduced by $\mathrm{H}_{2} / \mathrm{Ar}\left(\mathrm{H}_{2}: 10\right.$ vol. \%) with a flow of $30 \mathrm{~mL} / \mathrm{min}$ in the temperature range of $50-600^{\circ} \mathrm{C}$ at a heating rate of $10^{\circ} \mathrm{C} / \mathrm{min}$. Diffuse reflectance spectroscopy (DRS) was measured on Agilent Cary 5000 UV-vis spectrophotometer (Agilent, Santa Clara, CA, USA) in the range of $200-800 \mathrm{~nm}$. The band gaps were estimated by extrapolating a linear part of the plots to $(\alpha \mathrm{h} v)^{0.5}=0$. The photoluminescence (PL) spectra were obtained using Hitachi F-4500 fluorescence spectrophotometer (Hitachi, Ibaraki, Japan) with optical filter and the excitation wavelength at $300 \mathrm{~nm}$. Mott-Schottky plots were derived from impedance-potential at a frequency of $10 \mathrm{KHz}$ by a CHI 660D electrochemical station (Chenhua Ltd., Shanghai, China) in the dark. $1 \mathrm{M}$ $\mathrm{NaOH}$ aqueous solution $(\mathrm{pH}=13.6)$ was used as an electrolyte. Saturated calomel electrode (SCE) and $\mathrm{Pt}$ wire were used as reference and counter electrode, respectively.

\section{Conclusions}

$\mathrm{TiO}_{2-x}$ nanoribbons with abundant stable surface oxygen vacancies was prepared by hydrogen-etching technology. The WGS catalytic activities and stabilities of gold supported on hydrogen-etched $\mathrm{TiO}_{2-x}$ catalyst are obviously higher than those of gold supported on traditional white $\mathrm{TiO}_{2}$ catalysts. Firstly, the reduction of the surface oxygen species led to disorder of layers and abundant stable surface oxygen vacancies, which resulted in higher microstrain and more metallic $\mathrm{Au}^{0}$ species, respectively. These are beneficial to higher WGS activities. Secondly, disorder layers and stable surface oxygen vacancies led to the narrowed forbidden band gap, enhanced electron density and efficient charge separation and transportation. Finally, an electron flow process for understanding the difference in WGS activity has been proposed. Hereinto, the narrowed forbidden band gap facilitates the reduction of the Ohmic barrier; thus, the transmission efficiency of "hot-electron flow" is improved. Meanwhile, the abundant surface oxygen vacancies are functional as electron traps; thus, promoting the flow of "hot-electron" and reduction reaction of $\mathrm{H}_{2} \mathrm{O}$, so as to enhance the WGS catalytic activity.

Supplementary Materials: The following are available online at www.mdpi.com/2073-4344/8/1/26/s1, Figure S1: XPS spectra of various $\mathrm{TiO}_{2}$ supports and $\mathrm{Au}-\mathrm{TiO}_{2}$ catalysts, Figure S2: Schematic structure of white and blue black $\mathrm{TiO}_{2}$, Table S1: Physical properties of $\mathrm{Au}-\mathrm{TiO}_{2}$ and $\mathrm{Au}-\mathrm{TiO}_{2-x}$ catalysts, Table S2: Comparison of water-gas shift rates of $\mathrm{Au}-\mathrm{TiO}_{2-x}-\mathrm{N}$ catalysts with literature data, Table S3: Microstructure parameters of monoclinic $\mathrm{TiO}_{2}$ in various $\mathrm{TiO}_{2}$ supports and $\mathrm{Au}-\mathrm{TiO}_{2}$ catalysts.

Acknowledgments: This research was financially supported by the National Natural Science Foundation of China (21503092), the Zhejiang Provincial Natural Science Foundation of China (LQ18B030006) and Zhejiang Provincial Analysis and Measurement Foundation of China (2018C37077).

Author Contributions: Li Song and Lei Li conceived and designed the experiments; Li Song, Zhufeng Lu, Yuting Zhang, Qi Su and Lei Li performed the experiments; Li Song and Lei Li analyzed the data; Li Song and Lei Li wrote the paper.

Conflicts of Interest: The authors declare no conflict of interest.

\section{References}

1. Flytzani-Stephanopoulos, M. Gold atoms stabilized on various supports catalyze the water-gas shift reaction. Acc. Chem. Res. 2013, 47, 783-792. [CrossRef] [PubMed]

2. Bunluesin, T.; Gorte, R.J.; Graham, G.W. Studies of the water-gas-shift reaction on ceria-supported Pt, Pd, and Rh: Implications for oxygen-storage properties. Appl. Catal. B Environ. 1998, 15, 107-114. [CrossRef]

3. Hakeem, A.A.; Vásquez, R.S.; Rajendran, J.; Li, M.; Berger, R.J.; Delgado, J.J.; Kapteijn, F.; Makkee, M. The role of rhodium in the mechanism of the water-gas shift over zirconia supported iron oxide. J. Catal. 2014, 313, 34-45. [CrossRef]

4. Li, Y.; Fu, Q.; Flytzani-Stephanopoulos, M. Low-temperature water-gas shift reaction over Cu- and Ni-loaded cerium oxide catalysts. Appl. Catal. B Environ. 2000, 27, 179-191. [CrossRef] 
5. Ren, Z.; Peng, F.; Li, J.; Liang, X.; Chen, B. Morphology-Dependent Properties of $\mathrm{Cu} / \mathrm{CeO}_{2}$ Catalysts for the Water-Gas Shift Reaction. Catalysts 2017, 7, 48. [CrossRef]

6. Sakurai, H.; Ueda, A.; Kobayashi, T.; Haruta, M. Low-temperature water-gas shift reaction over gold deposited on $\mathrm{TiO}_{2}$. Chem. Commun. 1997, 0, 271-272. [CrossRef]

7. Ma, Z.; Yin, H.F.; Dai, S. Performance of $\mathrm{Au} / \mathrm{M}_{x} \mathrm{O}_{y} / \mathrm{TiO}_{2}$ Catalysts in water-gas shift reaction. Catal. Lett. 2010, 136, 83-91. [CrossRef]

8. Shi, J.; Mahr, C.; Mangir Murshed, M.; Zielasek, V.; Rosenauer, A.; Gesing, T.M.; Bäumer, M.; Wittstock, A. A versatile sol-gel coating for mixed oxides on nanoporous gold and their application in the water gas shift reaction. Catal. Sci. Technol. 2016, 6, 5311-5319. [CrossRef]

9. Faust, M.; Dinkel, M.; Bruns, M.; Bräse, S.; Seipenbusch, M. Support Effect on the Water Gas Shift Activity of Chemical Vapor Deposition-Tailored-Pt/ $\mathrm{TiO}_{2}$ Catalysts. Ind. Eng. Chem. Res. 2017, 56, 3194-3203. [CrossRef]

10. Yang, M.; Allard, L.F.; Flytzani-Stephanopoulos, M. Atomically Dispersed Au- $(\mathrm{OH})_{x}$ Species Bound on Titania Catalyze the Low-Temperature Water-Gas Shift Reaction. J. Am. Chem. Soc. 2013, 135, 3768-3771. [CrossRef] [PubMed]

11. Wang, J.; Kispersky, V.F.; Nicholas Delgass, W.; Ribeiro, F.H. Determination of the Au active site and surface active species via operando transmission FTIR and isotopic transient experiments on $2.3 \mathrm{wt}$. \% $\mathrm{Au} / \mathrm{TiO}_{2}$ for the WGS reaction. J. Catal. 2012, 289, 171-178. [CrossRef]

12. Shekhar, M.; Wang, J.; Lee, W.S.; Williams, W.D.; Kim, S.M.; Stach, E.A.; Miller, J.T.; Delgass, W.N.; Ribeiro, F.H. Size and support effects for the water-gas shift catalysis over gold nanoparticles supported on model $\mathrm{Al}_{2} \mathrm{O}_{3}$ and $\mathrm{TiO}_{2}$. J. Am. Chem. Soc. 2012, 134, 4700-4708. [CrossRef] [PubMed]

13. Panagiotopoulou, P.; Kondarides, D.I. Effects of alkali promotion of $\mathrm{TiO}_{2}$ on the chemisorptive properties and water-gas shift activity of supported noble metal catalysts. J. Catal. 2009, 267, 57-66. [CrossRef]

14. Pérez, P.; Soria, M.A.; Carabineiro, S.A.C.; Maldonado-Hódar, F.J.; Mendes, A.; Madeira, L.M. Application of $\mathrm{Au} / \mathrm{TiO}_{2}$ catalysts in the low-temperature water-gas shift reaction. Int. J. Hydrogen Energy 2016, 41, 4670-4681. [CrossRef]

15. Hinojosa-Reyes, M.; Rodríguez-González, V.; Zanella, R. Gold nanoparticles supported on $\mathrm{TiO}_{2}-\mathrm{Ni}_{\text {as }}$ catalysts for hydrogen purification via water-gas shift reaction. RSC Adv. 2014, 4, 4308-4316. [CrossRef]

16. Zhu, X.; Shen, M.; Lobban, L.L.; Mallinson, R.G. Structural effects of Na promotion for high water gas shift activity on Pt-Na/TiO 2 . J. Catal. 2011, 278, 123-132. [CrossRef]

17. Rodriguez, J.A.; Ramírez, P.J.; Asara, G.G.; Viñes, F.; Evans, J.; Liu, P.; Ricart, J.M.; Illas, F. Charge Polarization at a $\mathrm{Au}-\mathrm{TiC}$ Interface and the Generation of Highly Active and Selective Catalysts for the Low-Temperature Water-Gas Shift Reaction. Angew. Chem. Int. Ed. 2014, 53, 11270-11274. [CrossRef] [PubMed]

18. Li, L.; Zhan, Y.; Zheng, Q.; Zheng, Y.; Chen, C.; She, Y.; Lin, X.; Wei, K. Water-Gas Shift Reaction over $\mathrm{CuO} / \mathrm{CeO}_{2}$ Catalysts: Effect of the Thermal Stability and Oxygen Vacancies of $\mathrm{CeO}_{2}$ Supports previously prepared by different methods. Catal. Lett. 2009, 130, 532-540. [CrossRef]

19. Duarte de Farias, A.M.; Nguyen-Thanh, D.; Fraga, M.A. Discussing the use of modified ceria as support for Pt catalysts on water-gas shift reaction. Appl. Catal. B Environ. 2010, 93, 250-258. [CrossRef]

20. Hwang, K.R.; Park, J.S.; Ihm, S.K. Si-modified Pt/CeO 2 catalyst for a single-stage water-gas shift reaction. Int. J. Hydrogen Energy 2011, 36, 9685-9693. [CrossRef]

21. Montini, T.; Melchionna, M.; Monai, M.; Fornasiero, P. Fundamentals and Catalytic Applications of $\mathrm{CeO}_{2}$-Based Materials. Chem. Rev. 2016, 116, 5987-6041. [CrossRef] [PubMed]

22. González-Castaño, M.; Ivanova, S.; Ioannides, T.; Centeno, M.A.; Odriozola, J.A. Deep insight into Zr/Fe combination for successful $\mathrm{Pt} / \mathrm{CeO}_{2} / \mathrm{Al}_{2} \mathrm{O}_{3}$ WGS catalyst doping. Catal. Sci. Technol. 2017, 7, 1556-1564. [CrossRef]

23. Bobrova, L.; Andreev, D.; Ivanov, E.; Mezentseva, N.; Simonov, M.; Makarshin, L.; Cribovskii, A.; Sadykov, V. Water-gas shift reaction over $\mathrm{Ni} / \mathrm{CeO}_{2}$ catalysts. Catalysts 2017, 7, 310. [CrossRef]

24. Wyvratt, B.M.; Gaudet, J.R.; Thompson, L.T. Effects of passivation on synthesis, structure and composition of molybdenum carbide supported platinum water-gas shift catalysts. J. Catal. 2015, 330, 280-287. [CrossRef]

25. Posada-Pérez, S.; Gutiérez, R.A.; Zuo, Z.; Ramírez, P.J.; Viñes, F.; Liu, P.; Illas, F.; Rodriguez, J.A. Highly active $\mathrm{Au} / \delta-\mathrm{MoC}$ and $\mathrm{Au} / \beta-\mathrm{Mo}_{2} \mathrm{C}$ catalysts for the low-temperature water gas shift reaction: Effects of the carbide metal/carbon ratio on the catalyst performance. Catal. Sci. Technol. 2017, 7, 5332-5342. [CrossRef]

26. Schweitzer, N.M.; Schaidle, J.A.; Ezekoye, O.K.; Pan, X.; Linic, S.; Thompson, L.T. High Activity Carbide Supported Catalysts for Water Gas Shift. J. Am. Chem. Soc. 2011, 133, 2378-2381. [CrossRef] [PubMed] 
27. Lin, J.; Wang, A.; Qiao, B.; Liu, X.; Yang, X.; Wang, X.; Liang, J.; Li, J.; Liu, J.; Zhang, T. Remarkable performance of $\mathrm{Ir}_{1} / \mathrm{FeO}_{x}$ single-atom catalyst in water-gas shift reaction. J. Am. Chem. Soc. 2013, 135, 15314-15317. [CrossRef] [PubMed]

28. Dufour, J.; Martos, C.; Ruiz, A.; Ayuela, F.J. Effect of the precursor on the activity of high temperature water gas shift catalysts. Int. J. Hydrogen Energy 2013, 38, 7647-7653. [CrossRef]

29. Soria, M.A.; Pérez, P.; Carabineiro, S.A.C.; Maldonado-Hódar, F.J.; Mendes, A.; Madeira, L.M. Effect of the preparation method on the catalytic activity and stability of $\mathrm{Au} / \mathrm{Fe}_{2} \mathrm{O}_{3}$ catalysts in the low-temperature water-gas shift reaction. Appl. Catal. A Gen. 2014, 470, 45-55. [CrossRef]

30. Kono, E.; Tamura, S.; Yamamuro, K.; Ogo, S.; Sekine, Y. Pd/K/Co-oxide catalyst for water gas shift. Appl. Catal. A Gen. 2015, 489, 247-254. [CrossRef]

31. Cybulskis, V.J.; Wang, J.; Pazmiño, J.H.; Ribeiro, F.H.; Delgass, W.N. Isotopic transient studies of sodium promotion of $\mathrm{Pt} / \mathrm{Al}_{2} \mathrm{O}_{3}$ for the water-gas shift reaction. J. Catal. 2016, 339, 163-172. [CrossRef]

32. Lenite, B.A.; Galletti, C.; Specchia, S. Studies on Au catalysts for water gas shift reaction. Int. J. Hydrogen Energy 2011, 36, 7750-7758. [CrossRef]

33. Tibiletti, D.; Meunier, F.C.; Goguet, A.; Reid, D.; Burch, R.; Boaro, M.; Vicario, M.; Trovarelli, A. An investigation of possible mechanisms for the water-gas shift reaction over a $\mathrm{ZrO}_{2}$-supported $\mathrm{Pt}$ catalyst. J. Catal. 2006, 244, 183-191. [CrossRef]

34. Zhang, Y.; Zhan, Y.; Chen, C.; Cao, Y.; Lin, X.; Zheng, Q. Highly efficient $\mathrm{Au} / \mathrm{ZrO}_{2}$ catalysts for low-temperature water-gas shift reaction: Effect of pre-calcination temperature of $\mathrm{ZrO}_{2}$. Int. J. Hydrogen Energ. 2012, 37, 12292-12300. [CrossRef]

35. Luo, S.; Barrio, L.; Nguyen-Phan, T.D.; Vovchok, D.; Johnston-Peck, A.C.; Xu, W.; Stach, E.A.; Rodriguez, J.A.; Senanayake, S.D. Importance of Low Dimensional $\mathrm{CeO}_{x}$ Nanostructures in $\mathrm{Pt} / \mathrm{CeO}_{x}-\mathrm{TiO}_{2}$ Catalysts for the Water-Gas Shift Reaction. J. Phys. Chem. C 2017, 121, 6635-6642. [CrossRef]

36. Silva, L.P.C.; Terra, L.E.; Coutinho, A.C.; Passos, F.B. Sour water-gas shift reaction over Pt/CeZrO 2 catalysts. J. Catal. 2016, 341, 1-12. [CrossRef]

37. Daly, H.; Goguet, A.; Hardacre, C.; Meunier, F.C.; Pilasombat, R.; Thompsett, D. The effect of reaction conditions on the stability of $\mathrm{Au} / \mathrm{CeZrO}_{4}$ catalysts in the low-temperature water-gas shift reaction. J. Catal. 2010, 273, 257-265. [CrossRef]

38. Sun, Y.; Hla, S.S.; Duffy, G.J.; Cousins, A.J.; French, D.; Morpeth, L.D.; Edwards, J.H.; Roberts, D.G. A comparative study of $\mathrm{CeO}_{2}-\mathrm{La}_{2} \mathrm{O}_{3}$-based $\mathrm{Cu}$ catalysts for the production of hydrogen from simulated coal-derived syngas. Appl. Catal. A Gen. 2010, 390, 201-209. [CrossRef]

39. Rodriguez, J.A. Gold-based catalysts for the water-gas shift reaction: Active sites and reaction mechanism. Catal. Today 2011, 160, 3-10. [CrossRef]

40. Williams, W.D.; Greeley, J.P.; Delgass, W.N.; Ribeiro, F.H. Water activation and carbon monoxide coverage effects on maximum rates for low temperature water-gas shift catalysis. J. Catal. 2017, 347, $197-204$. [CrossRef]

41. Ammal, S.C.; Heyden, A. Water-Gas Shift Catalysis at Corner Atoms of Pt Clusters in Contact with a $\mathrm{TiO}_{2}$ (110) Support Surface. ACS Catal. 2014, 4, 3654-3662. [CrossRef]

42. Lin, Y.; Wu, Z.; Wen, J.; Ding, K.; Yang, X.; Poeppelmeier, K.R.; Marks, L.D. Adhesion and Atomic Structures of Gold on Ceria Nanostructures: The Role of Surface Structure and Oxidation State of Ceria Supports. Nano Lett. 2015, 15, 5375-5381. [CrossRef] [PubMed]

43. Rodriguez, J.A.; Graciani, J.; Evans, J.; Park, J.B.; Yang, F.; Stacchiola, D.; Senanayake, S.D.; Ma, S.; Pérez, M.; Liu, P.; et al. Water-Gas Shift Reaction on a Highly Active Inverse $\mathrm{CeO}_{x} / \mathrm{Cu}(111)$ Catalyst: Unique Role of Ceria Nanoparticles. Angew. Chem. 2009, 121, 8191-8194. [CrossRef]

44. Graciani, J.; Sanz, J.F. Designing a new generation of catalysts: Water gas shift reaction example. Catal. Today 2015, 240, 214-219. [CrossRef]

45. Rodríguez, J.A.; Evans, J.; Graciani, J.; Park, J.B.; Liu, P.; Hrbek, J.; Sanz, J.F. High Water-Gas Shift Activity in $\mathrm{TiO}_{2}(110)$ Supported $\mathrm{Cu}$ and Au Nanoparticles: Role of the Oxide and Metal Particle Size. J. Phys. Chem. C 2009, 113, 7364-7370. [CrossRef]

46. Goddeti, K.C.; Kim, S.M.; Lee, Y.K.; Kim, S.H.; Park, J.Y. Chemical Doping of $\mathrm{TiO}_{2}$ with Nitrogen and Fluorine and Its Support Effect on Catalytic Activity of CO Oxidation. Catal. Lett. 2014, 144, 1411-1417. [CrossRef] 
47. Chen, X.; Liu, L.; Peter, Y.Y.; Mao, S.S. Increasing Solar Absorption for Photocatalysis with Black Hydrogenated Titanium Dioxide Nanocrystals. Science 2011, 331, 746-750. [CrossRef] [PubMed]

48. Panagiotopoulou, P.; Christodoulakis, A.; Kondarides, D.I.; Boghosian, S. Particle size effects on the reducibility of titanium dioxide and its relation to the water-gas shift activity of $\mathrm{Pt} / \mathrm{TiO}_{2}$ catalysts. J. Catal. 2006, 240, 114-125. [CrossRef]

49. Yang, C.; Wang, Z.; Lin, T.; Yin, H.; Lü, X.; Wan, D.; Xu, T.; Zheng, C.; Lin, J.; Huang, F.; et al. Core-Shell Nanostructured "Black" Rutile Titania as Excellent Catalyst for Hydrogen Production Enhanced by Sulfur Doping. J. Am. Chem. Soc. 2013, 135, 17831-17838. [CrossRef] [PubMed]

50. Zhou, W.; Li, W.; Wang, J.; Qu, Y.; Yang, Y.; Xie, Y.; Zhang, K.; Wang, L.; Fu, H.; Zhao, D. Ordered Mesoporous Black $\mathrm{TiO}_{2}$ as Highly Efficient Hydrogen Evolution Photocatalyst. J. Am. Chem. Soc. 2014, 136, 9280-9283. [CrossRef] [PubMed]

51. Naldoni, A.; Allieta, M.; Santangelo, S.; Marelli, M.; Fabbri, F.; Cappelli, S.; Bianchi, C.L.; Psaro, R.; Santo, V.D. Effect of Nature and Location of Defects on Bandgap Narrowing in Black $\mathrm{TiO}_{2}$ Nanoparticles. J. Am. Chem. Soc. 2012, 134, 7600-7603. [CrossRef] [PubMed]

52. Zheng, Z.; Huang, B.; Lu, J.; Wang, Z.; Qin, X.; Zhang, X.; Dai, Y.; Whangbo, M.H. Hydrogenated titania: Synergy of surface modification and morphology improvement for enhanced photocatalytic activity. Chem. Commun. 2012, 48, 5733-5735. [CrossRef] [PubMed]

53. Wang, Z.; Yang, C.; Lin, T.; Yin, H.; Chen, P.; Wan, D.; Xu, F.; Huang, F.; Lin, J.; Xie, X.; et al. Visible-light Photocatalytic, Solar Thermal and Photoelectrochemical Properties of Aluminium-reduced Black Titania. Energy Environ. Sci. 2013, 6, 3007-3014. [CrossRef]

54. Lu, X.; Wang, G.; Zhai, T.; Yu, M.; Gan, J.; Tong, Y.; Li, Y. Hydrogenated $\mathrm{TiO}_{2}$ Nanotube Arrays for Supercapacitors. Nano Lett. 2012, 12, 1690-1696. [CrossRef] [PubMed]

55. He, Y.J.; Peng, J.F.; Chu, W.; Li, Y.Z.; Tong, D.G. Black mesoporous anatase $\mathrm{TiO}_{2}$ nanoleaves: A high capacity and high rate anode for aqueous Al-ion batteries. J. Mater. Chem. A 2014, 2, 1721-1731. [CrossRef]

56. Kim, S.M.; Lee, H.; Park, J.Y. Charge Transport in Metal-Oxide Interfaces: Genesis and Detection of Hot Electron Flow and Its Role in Heterogeneous Catalysis. Catal. Lett. 2015, 145, 299-308. [CrossRef]

57. Park, J.Y.; Lee, H.; Renzas, J.R.; Zhang, Y.; Somorjai, G.A. Probing Hot Electron Flow Generated on Pt Nanoparticles with $\mathrm{Au} / \mathrm{TiO}_{2}$ Schottky Diodes during Catalytic CO Oxidation. Nano Lett. 2008, 8, $2388-2392$. [CrossRef] [PubMed]

58. Furube, A.; Du, L.; Hara, K.; Katoh, R.; Tachiya, M. Ultrafast Plasmon-Induced Electron Transfer from Gold Nanodots into $\mathrm{TiO}_{2}$ Nanoparticles. J. Am. Chem. Soc. 2007, 129, 14852-14853. [CrossRef] [PubMed]

59. Jiang, X.; Lu, G.; Zhou, R.; Mao, J.; Chen, Y.; Zheng, X. Studies of pore structure, temperature-programmed reduction performance, and micro-structure of $\mathrm{CuO} / \mathrm{CeO}_{2}$ catalysts. Appl. Surf. Sci. 2001, 173, $208-220$. [CrossRef]

60. Li, L.; Song, L.; Chen, C.; Zhang, Y.; Zhan, Y.; Lin, X.; Zheng, Q.; Wang, H.; Ma, H.; Ding, L.; et al. Modified precipitation processes and optimized copper content of $\mathrm{CuO}-\mathrm{CeO}_{2}$ catalysts for water-gas shift reaction. Int. J. Hydrogen Energy 2014, 39, 19570-19582. [CrossRef]

61. Li, L.; Song, L.; Wang, H.; Chen, C.; She, Y.; Zhan, Y.; Lin, X.; Zheng, Q. Water-Gas Shift Reaction over $\mathrm{CuO} / \mathrm{CeO}_{2}$ Catalysts: Effect of $\mathrm{CeO}_{2}$ Supports previously prepared by precipitation with different precipitants. Int. J. Hydrogen Energy 2011, 36, 8839-8849. [CrossRef]

62. Beuvier, T.; Richard-Plouet, M.; Brohan, L. Accurate Methods for Quantifying the Relative Ratio of Anatase and $\mathrm{TiO}_{2}$ (B) Nanoparticles. J. Phys. Chem. C 2009, 113, 13703-13706. [CrossRef]

63. Hemmingson, S.L.; James, T.E.; Feeley, G.M.; Tilson, A.M.; Campbell, C.T. Adsorption and Adhesion of Au on Reduced $\mathrm{CeO}_{2}$ (111) Surfaces at 300 and 100 K. J. Phys. Chem. C 2016, 120, 12113-12124. [CrossRef]

64. Li, B.; Zhao, Z.; Zhou, Q.; Meng, B.; Meng, X.; Qiu, J. Highly Efficient Low-Temperature Plasma-Assisted Modification of $\mathrm{TiO}_{2}$ Nanosheets with Exposed $\{001\}$ Facets for Enhanced Visible-Light Photocatalytic Activity. Chem. Eur. J. 2014, 20, 14763-14770. [CrossRef] [PubMed]

65. Kruse, N.; Chenakin, S. XPS characterization of $\mathrm{Au} / \mathrm{TiO}_{2}$ catalysts: Binding energy assessment and irradiation effects. Appl. Catal. A Gen. 2011, 391, 367-376. [CrossRef]

66. Kast, P.; Kučerová, G.; Behm, R.J. On the nature of the active Au species: CO oxidation on cyanide leached $\mathrm{Au} / \mathrm{TiO}_{2}$ catalysts. Catal. Today 2015, 244, 146-160. [CrossRef] 
67. Magadzu, T.; Yang, J.H.; Henao, J.D.; Kung, M.C.; Kung, H.H.; Scurrell, M.S. Low-Temperature Water-Gas Shift Reaction over Au Supported on Anatase in the Presence of Copper: EXAFS/XANES Analysis of Gold-Copper Ion Mixtures on $\mathrm{TiO}_{2}$. J. Phys. Chem. C 2017, 121, 8812-8823. [CrossRef]

68. Wang, G.; Wang, H.; Ling, Y.; Tang, Y.; Yang, X.; Fitzmorris, R.C.; Wang, C.; Zhang, J.Z.; Li, Y. Hydrogen-Treated $\mathrm{TiO}_{2}$ Nanowire Arrays for Photoelectrochemical Water Splitting. Nano Lett. 2011, 11, 3026-3033. [CrossRef] [PubMed]

69. Sastre, F.; Oteri, M.; Corma, A.; García, H. Photocatalytic water gas shift using visible or simulated solar light for the efficient, room-temperature hydrogen generation. Energy Environ. Sci. 2013, 6, 2211-2215. [CrossRef]

70. Deáka, P.; Kullgren, J.; Aradi, B.; Frauenheim, T.; Kavan, L. Water splitting and the band edge positions of $\mathrm{TiO}_{2}$. Electrochim. Acta 2016, 199, 27-34. [CrossRef]

71. Zheng, Y.; Zheng, L.; Zhan, Y.; Lin, X.; Zheng, Q.; Wei, K. Ag/ZnO Heterostructure Nanocrystals: Synthesis, Characterization, and Photocatalysis. Inorg. Chem. 2007, 46, 6980-6986. [CrossRef] [PubMed]

72. Wang, X.; Kong, X.; Yu, Y.; Zhang, H. Synthesis and Characterization of Water-Soluble and Bifunctional ZnO-Au Nanocomposites. J. Phys. Chem. C 2007, 111, 3836-3841. [CrossRef]

73. Park, J.Y.; Baker, L.R.; Somorjai, G.A. Role of Hot Electrons and Metal-Oxide Interfaces in Surface Chemistry and Catalytic Reactions. Chem. Rev. 2015, 115, 2781-2817. [CrossRef] [PubMed]

74. Nedrygailov, I.I.; Lee, C.; Moon, S.Y.; Lee, H.; Park, J.Y. Hot Electrons at Solid-Liquid Interfaces: A Large Chemoelectric Effect during the Catalytic Decomposition of Hydrogen Peroxide. Angew. Chem. Int. Ed. 2016, 55, 10859-10862. [CrossRef] [PubMed]

75. Renzas, J.R.; Somorjai, G.A. Rh Thin-Film Nanocatalysts as Chemical Sensors-The Hot Electron Effect. J. Phys. Chem. C 2010, 114, 17660-17664. [CrossRef]

76. Maximoff, S.N.; Head-Gordon, M.P. Chemistry of fast electrons. Proc. Natl. Acad. Sci. USA 2009, 106, 11460-11465. [CrossRef] [PubMed]

77. Gergen, B.; Nienhaus, H.; Weinberg, W.H.; McFarland, E.W. Chemically Induced Electronic Excitations at Metal Surfaces. Science 2001, 294, 2521-2523. [CrossRef] [PubMed]

78. Nienhaus, H.; Bergh, H.S.; Gergen, B.; Majumdar, A.; Weinberg, W.H.; McFarland, E.W. Electron-Hole Pair Creation at $\mathrm{Ag}$ and $\mathrm{Cu}$ Surfaces by Adsorption of Atomic Hydrogen and Deuterium. Phys. Rev. Lett. 1999, 82, 446-449. [CrossRef]

79. Meier, D.C.; Goodman, D.W. The Influence of Metal Cluster Size on Adsorption Energies: CO Adsorbed on Au Clusters Supported on $\mathrm{TiO}_{2}$. J. Am. Chem. Soc. 2004, 126, 1892-1899. [CrossRef] [PubMed]

80. Green, I.X.; Tang, W.; Neurock, M.; Yates, J.T., Jr. Spectroscopic Observation of Dual Catalytic Sites during Oxidation of $\mathrm{CO}$ on a Au/ $\mathrm{TiO}_{2}$ Catalyst. Science 2011, 333, 736-739. [CrossRef] [PubMed]

81. Hammer, N.; Kvande, I.; Van Beek, W.; Chen, D.; Rønning, M. Identification of valence shifts in Au during the water-gas shift reaction. Top. Catal. 2007, 45, 25-29. [CrossRef]

82. Liu, Z.; Jenkins, S.J.; King, D.A. Origin and Activity of Oxidized Gold in Water-Gas-Shift Catalysis. Phys. Rev. Lett. 2005, 94, 196102-196104. [CrossRef] [PubMed]

83. Cao, X.; Zhou, J.; Wu, Y.; Tang, L.; Zhu, L.; Gu, L. Self-assembled, robust titanate nanoribbon membranes for highly efficient nanosolid capture and molecule discrimination. Nanoscale 2013, 5, 3486-3495. [CrossRef] [PubMed]

84. Otto, T.; Zones, S.I.; Iglesia, E. Challenges and strategies in the encapsulation and stabilization of monodisperse Au clusters within zeolites. J. Catal. 2016, 339, 195-208. [CrossRef]

(C) 2018 by the authors. Licensee MDPI, Basel, Switzerland. This article is an open access article distributed under the terms and conditions of the Creative Commons Attribution (CC BY) license (http://creativecommons.org/licenses/by/4.0/). 